\title{
PROGRESISMO Y PODER POLÍTICO EN LA ESPAÑA ISABELINA: EL GOBIERNO DE OLÓZAGA A FINALES DE 1843.
}

\author{
por \\ Gracla GómEZ URDÁÑEZ \\ Universidad de Zaragoza
}

RESUMEN: Precedido de una contextualización introductoria, el nucleo central de este artículo se ocupa principalmente de la formación del gabierno Olózaga y su caída en 1843. Se trata de un wpasajex prácticamente desconocido en la trayectoria politica del $h$ beralismo durante el reinado de Isabel II. La importancia de desentrafiarlo reside en su valor explicativo para comprender el pensamiento y la actitud polltica de Olbzaga como principal dirigente prograsista; objetivo que pretende, al mismo tiempo, obtener claves interpretativas sobre el progresismo español, al menos basta La inauguración de la decada moderada.

Palabras clave: Biografia. Parlamentarismo. Progresismo. Poder político. Olózaga. Espartero.

ABSTRACT: After an introductory contextualisation, the central core of this article deals mainly with the formation of the Olbraga government and its fall in 1843. This is a practically unknown chapter in the political bistory of liberalism during the reign of Lsabel II which is of particular importance because it throws light on the thinking and the political attitude of Olozaga as the main prognessive leader. The article also seeks to provide dues to enable a greater understanding of Spanish progressivism in the period before the beginning of the smaderate decadew.

KeY wORDS: Biography. Parliamentarism. «Progresismo». Policical power. Olbzaga. Espartero.

Desde la inauguración en 1834 del régimen representativo hasta el inicio de la década moderada, transcurrieron casi diez años de agitada existencia para

Hèpania, LX/2, лúm. 205 (2000) 623-672 
el liberalismo español y el proyecto político de la burguesía revolucionaria. En ocasiones, sin tener en cuenta que aquella fue una etapa de formación - por lo tanto, contradictoria y ambigua - buena parte de la historiografía ha venido reprochando indefinición a los comportamientos políticos y demasiada turbulencia a los hechos históricos. Rápidos cambios ministeriales, continuas convocatorias electorales, una sucesión vertiginosa de acontecimientos y protagonistas, y una guerra civil —causa y efecto, al mismo tiempo, de la situación política- fueron los componentes básicos de ese tiempo histórico, caracterizado, en efecto, por una indeterminación ideológica y una improvisación práctica acordes con el proceso de gestación de un nuevo sistema de poder.

Es notoria en la historiografía la falta de atención a este periodo en comparación con la investigación dedicada a otras etapas del XIX español, y quizás haya que atribuir ese desinterés a la dificultad que supone analizar con planteamientos convencionales aquellos diez años críticos para el asentamiento definitivo del régimen constitucional español y la construcción del Estado burgués. Con un afán meramente enunciativo, unos se han preocupado de ordenar los hechos y otros de encasillat a sus agentes; pero apenas existen trabajos sólidos que, a pesar de la renovación de la historia política, supongan un avance en la interpretación de la décadal. Si el periodo en su conjunto ha sido insuficientemente tratado, todavía es más palpable la ausencia de estudios sobre la regencia esparterista, y ya el tiempo que medió entre la caída de Espartero y el comienzo de la década moderada, se viene saldando, en el mejor de los casos, con un apresurado resumen que, a modo de prólogo, se limita a introducir los diez años moderados; espacio histórico que, por su mayor unidad política y su más apreciable coherencia desde el punto de vista interpretativo, ha contado con más dedicación historiográfica ${ }^{2}$.

Sin embargo, y por expresarlo en términos coloquiales, para que podamos hablar de la apertura de una nueva etapa, otra se habrá tenido que cerrar. Así, entre el final de la regencia de Espartero y el comienzo de la década moderada, hay un tiempo histórico — casi siempre obviado- cuyo desconocimiento inte-

\footnotetext{
1 Sobre la transformación de la historia política y las principales directrices que han seguido los cambios operados en este campo de investigación, véanse fundamentalmente Pedro Carasa, «La recuperación de la historia política y la prosopografian, en CARASA, P., ed.: Élites. Prosopograffía contemporánea, Universidad de Valladolid, Valladolid, 1994, pp. 41-51; o también Teresa Carnero, «La renovación de la Historia Polítican, en MORAles MOYA, A. y Esteban DE Vega, M., eds.: La Historia Contemporánea en España, Universidad de Salamanca, Salamanca, 1996, pp. 173-181.

2 María Cruz Romeo todavía alargaba más en el tiempo esta queja sobre carencias historiográficas. Su reivindicación incluía todo el periodo isabelino $\mathrm{y}$, aunque ehaya alguien que considere este juicio extremo", es preciso reconocer -continuaba la autora- "que el interés por la centuria pasada no ha implicado una idéntica preocupación por la etapa 1834-1868». El análisis de esce periodo se ha englobado en estudios más amplios, interesados, según María Cruz Romeo, en ofrecer «visiones de conjuntom sobre dos aspectos principales: «la revolución liberal y el desartollo del capitalismo en la Espafia del siglo XIXn. Véase "La política de Isabel II: comentario bibliográficon, Ayer, 29, 1998, p. 217.
} 
rrumpe el análisis del itinerario político del liberalismo, impide hacer un balance necesario sobre el significado histórico de los primeros años de constitucionalismo y régimen representativo en España desde la desaparición «oficial» del Antiguo Régimen, y en definitiva, como si al arco le faltara la clave, dificulta la comprensión tanto del periodo que cierra como del que abre. No es difícil apreciar la importancia de este breve -aunque intenso- espacio histórico, y sin embargo perdura en la historiografía su desestimación; circunstancia que, no por casualidad, coincide asimismo con la escasez de investigaciones y trabajos sobre el progresismo español. Si tenemos en cuenta que entre la caída de Espartero y los inicios de la década moderada, asistimos a la agonía progresista y al fin de su primera experiencia política continuada en el poder, podría concluirse que este deficitario tratamiento no es más que un nuevo capítulo de la mudez historiográfica que en general se mantiene sobre la historia del progresismo y los progresistas del siglo XIX español ${ }^{3}$.

Las páginas que siguen pretenden ser una aproximación a ese tiempo histórico que transcurre entre la crisis acelerada del progresismo y la llegada al poder de los moderados. Teniendo en cuenta que predomina una insuficiente exposición de lo sucedido después del exilio de Espartero y antes del primer gobierno Narváez, la propia acotación del tema exigirá en ocasiones una observación menuda y pormenorizada de la maraña política que, especialmente enredada a finales de 1843 , procede desmenuzar para facilitar la visión global de fenómenos más amplios. No obstante, el objetivo fundamental es facilitar la comprensión de la evolución, la adaptación, el fracaso o el éxito, el discurso, la práctica y los comportamientos contradictorios de las distintas alternativas de poder que participan en el proceso de formación y definición políticas del constitucionalismo español, con la intención más general de contribuir a la recuperación de claves para la interpretación histórica del liberalismo, el moderantismo, y sobre todo el progresismo, dentro de los años 1834-1843.

El planteamiento, además, se aborda desde la óptica metodológica de una biografía histórica; enfoque que admite $-y$, como un prisma, forma parte de su propia esencia - tanto la multiplicación de perspectivas, como al mismo tiempo el acercamiento al objeto de análisis ${ }^{4}$. Todavía de mayor eficacia puede

${ }^{3}$ Uno de los últimos pronunciamientos en este sentido también lo hacía María Cruz Romeo, quien denunciaba que utodavía no se ha realizado un análisis exhauscivo sobre el progresismo $y$ aquellos que se definían como tales»; existen algunas aproximaciones, por ejemplo, desde la historia constitucional, pero eno disponemos de un estudio global de la cultura política progresista». lbidem, p. 220.

4 Sobre la biografía y su recuperación como herramienta útil para el análisis histórico, véanse sobre todo LEvI, G.: «Les usages de la biographie», Annales E.S.C., 6, 1989, pp. 1.325-1.336; MoRALes MOYA, A.; «Biografía y narración en la histotiografia actual', en AA. VV., Problemas actuales de la Historia. Ill Jomadas de Estudios Históricos, Universidad de Salamanca, Salamanca, 1993, pp. 229-257; PIQUeRAS, José A.: «De la biografía tradicional a la historia individual, grupal y masiva», en CARASA, P.: ed., Élites ..., pp. 53-62; STROzZI, S.: «Sujeto y persona en la biografía histórica», 
resultat el uso de la biografía en este caso, toda vez que Salustiano de Olózaga, no sólo tuvo una implicación directa en los distintos acontecimientos que marcaron el periodo, sino que, además, dirigió a finales de 1843 un gobierno que a la postre resultó ser la última experiencia progresista en el poder hasta 1854 . Ha sido escasa su repercusión historiográfica, pero hasta la proclamación de la Primera República, Olózaga desempeñó un papel político determinante e intervino de manera decisiva en los principales acontecimientos históricos que vertebran el siglo XIX español. Hasta la muerte de Fernando VII, los rasgos biográficos más significativos en la vida del histórico progresista son los propios de toda una generación de liberales comprometidos con la demolición del Antiguo Régimen y la promoción de cambios en favor del ideario burgués. Instruido políticamente en las Sociedades Patrióticas y en la Milicia Nacional durante los años del Trienio, admirador de la filosofía de Bentham y conspirador clandestino durante la década ominosa, el protagonismo político de Olózaga fue creciendo de forma imparable a partir de los inicios del régimen parlamentario. Recién llegado al poder, Mendizábal le nombró gobernador civil de la provincia de Madrid y en 1836, al ser elegido procurador, dio comienzo su larga trayectoria parlamentaria. Hasta 1843 revalidó su acta de diputado en todas las legislaturas, se hizo con el liderazgo del progresismo y ejerció la dirección de su estrategia política, especialmente resonante en los momentos de oposición parlamentaria. En 1837 participó en la reforma de la Constitución, en 1840 llegó a la alcaldía de Madrid y en ese mismo año Espartero, regente provisional, le nombró enviado extraordinario y ministro plenipotenciario en París. Convertido en un político necesario y un hombre de considerable influencia, la trayectoria pública de Olózaga fue cobrando intensidad hasta que a finales de 1843 se le reclamó consensuadamente para sustituir en el gobierno a Joaquín María López. Después de 1843, su protagonismo histórico no decreció, y como principal dirigente del progresismo tuvo una participación directa en el bienio 1854-1856 y también en los preparativos de la revolución del $68^{5}$.

en BARros, C., ed.: Historia a debate. 3. Otros enfoques, Universidad de Santiago de Compostela, La Coruña, 1995, pp. 175-182; o también distintos artículos recogidos en el monográfico «A vueltas con el sujero» de la revista Historia Contemporánea, 13-14, 1996.

s Numerosos retratos lirerarios y semblanzas biográficas de la época se hicieron eco de su elevada categotía política, aunque el más destacado es el de FrRnández de LOS Ríos, Á.: Olózaga. Estudio politico y biográfico, Madrid, 1863. Posteriotmente, y a pesar de su gran trascendencia, apenas ha habido estudios específicos sobre este personaje, como tampoco sobre otros muchos protagonistas del siglo XIX. Tan sólo contamos con algunos esbozos - tímidos frutos de una línea de investigación enseguida abandonada - como, por ejemplo, la memoria de licenciatura inédita de FERNÁNDEZ DE NAVARRETE, I.: Contribución al estudio de la figura personal y politica de Don Salustiano de Olozaga y la política española del segundo tercio del siglo XIX, leída en la Universidad Complutense, Madrid, 1973; y el artículo de BERMEjo, Fr.: «Olózaga y Orovio o el caciquismo en el distrito riojano de Arnedo: 1846-1864», en Actas del Segundo Coloquio sobre Historia de La Rioja, Vol. II, C.U.R., Logroño, 1986, pp. 341-353.

Hispania, LX/2, nüm. 205 (2000) 623-672 
Tomando como referencia, por lo tanto, un personaje conductor de constatada relevancia histórica, se vincula estrechamente con el objetivo central el propósito de rescatar la figura de Olózaga y demostrar su extraordinaria importancia política durante todo el reinado isabelino. La evolución ideológica y el recorrido político de uno de los más importantes líderes progresistas del XIX, es al mismo tiempo el estudio de la formación, desarrollo y consolidación del sistema parlamentario en el liberalismo español. Ambos aspectos adquieren, por consiguiente, el mismo rango y se convierten en un único objetivo para la investigación ${ }^{6}$. En la medida en que el seguimiento del personaje es, en definitiva, una lectura paralela sobre el curso del liberalismo y la dirección de la revolución burguesa en España, el análisis sobre la evolución ideológica, las actitudes políticas y el gobierno de Olózaga en estos años claves para el asentamiento definitivo del régimen parlamentario y del nuevo sistema de poder, resulta imprescindible para trazar algunas directrices interpretativas con las que situar históricamente el fracaso de las expectativas progresistas y el rumbo político de la burguesía liberal en los inicios de la España isabelina.

\section{DEL ESTATUTO REAI A LA REVOLUCIÓN DEL 40: LA FORMACIÓN DE LAS AL- TERNATIVAS MODERADA Y PROGRESISTA EN LA PRÁCTICA POLÍTICA.}

La muerte de Fernando VII supuso para el liberalismo español una nueva oportunidad política. En un principio, a pesar de que la fuerza liberal se intuía imparable, ni la regente María Cristina ni el gobierno de Cea Bermúdez tuvieron vocación alguna de promover cambios bruscos en el orden establecido. Sin embargo, el estallido de la guerra carlista tras la desaparición del rey absoluto, ponía en peligro el futuro de Isabel II en la sucesión monárquica y la regente se vio obligada a consentir reformas a cambio del apoyo de los liberales en favor de la causa isabelina. La que en principio quiso ser tan sólo una tímida apertura acabó así propiciando la promulgación en 1834 del Estatuto Real, ley marco que sentaba los pilares básicos de la reglamentación parlamentaria y conformaba la estructura primaria del nuevo sistema de poder.

Desde la vigencia del Estatuto Real y como ya ocurriera durante los años 20 al 23, el liberalismo español, si bien compartía de manera unánime la esencia de los principales objetivos revolucionarios, empezó a manifestar su división respecto a la dirección estratégica de la práctica política. En un principio, el

\footnotetext{
6 Este es el tema de la tesis doctoral que actualmente realizo sobre la biografía política de Salustiano de Olózaga; investigación que, como corresponde a una biografia histótica, intenta traspasar los limites de una trayectoria individual para poder dar respuestas a preguntas más generales. Teniendo en cuenta que el personaje no es el fin sino el medio, el trabajo en curso quiere ser una aproximación a fenómenos históricos claves para comprender el periodo isabelino. Estos giran básicamente en torno al análisis de la formación de las élites, su desenvolvimiento histórico en el marco de la revolución burguesa y la naturaleza y ejercicio del poder político en la España de Isabel II.
} 
Estatuto satisfizo las expectativas inmediatas del liberalismo. Aunque de factura moderada, la ley reformista se debía a la inspiración política de Martínez de la Rosa, cuyo pasado ligado a la representación constitucional durante los años del Trienio, ofrecía suficientes garantías políticas a todos los liberales. Acogido favorablemente en un clima de prudencia invocada por todos, la obra de Martínez de la Rosa se limitó a disponer normas generales en materia electoral y dejó en manos de una legislación posterior su completo desarrollo ${ }^{7}$. Así, el decreto de 20 de mayo de 1834 convocaba las primeras elecciones a procuradores mediante sufragio censitario y por sistema indirecto en $2^{\circ}$ grado. Celebradas en el mes de junio, menos de mil individuos resultaron elegidos procuradores y la maquinaria parlamentaria podía ponerse en marcha con lo más distinguido de la clase propietaria ${ }^{8}$. Si en un principio ni el Estatuto ni tampoco la ley electoral habían despertado recelos entre aquellos sectores con más prisas por alcanzar las metas fijadas en el programa liberal, a partir de los resultados de estas elecciones, una tendencia progresista - cuya identidad política no distaba en lo esencial de los postulados moderados, pero sí se separaba en cuanto a los medios para alcanzar los fines- empezó a reivindicar un marco constitucional más amplio y una ley electoral que permitiera la participación política de más propietarios. Poco a poco y conforme avanzaba el peligro carlista, los liberales más progresistas creyeron -como los exaltados en el Trienio- que reformas tímidas como el Estatuto favorecían al enemigo, en este caso al carlismo, en la medida en que no permitían el agrupamiento de todas las fuerzas antirreaccionarias. $Y$ es que inmerso en una situación de guerra civil, la consistencia del régimen parlamentario se revelaba frágil y su duración resultaba impredecible. En un principio, estas circunstancias - a las que habría que añadir el recuerdo de las anteriores experiencias constitucionales violentamente frustradas- produjeron un lógico efecto de inhibición política y disimulo de actitudes?. Por lo

\footnotetext{
7 El proyecro inicial que Martínez de la Rosa sometió a la consideración del Consejo de Gobierno -órgano complementario de la regencia- incluyó una propuesta electoral más concreta, cuya conveniencia fue desaconsejada por algunos miembros del Consejo. En consecuencia, el Estatuto fue publicado prescindiendo de aquel apartado, cuyo desarrollo correspondería establecer después por vía legislativa a las primeras Cortes. Véase la explicación detallada de esta cuestión en Tomás VILARRoYA, J.: El sistema politico del Estatuto Real (1834-1836), Instituto de Estudios Políticos, Madrid, 1968, p. 66.

8 Para estas y ottas elecciones del periodo isabelino, véanse los trabajos de AGULAR, E.: Vida politica y pracesos electorales en la Córdoba isabelina (1834-1868), Caja de Ahorros de Córdoba, Córdoba, 1991; y CABALLERO, M.: El sufragio censitario. Elecciones generales en Soria durante el reinado de Isabel II, Junta de Castilla y León, Ávila, 1994. De esta úlcima autora, véase también su artículo reciente sobre la legislación electoral del reinado isabelino, «El derecho de representación: sufragio y leyes electorales", Ayer, 34, 1999, pp. 41-63.

9 Sobre el retraimiento polírico en estas fechas tempranas, la historiografia ha experimentado en los últimos años un avance muy significativo gracias a la investigación de Margarita Caballero sobre las elecciones en el reinado de Isabel II. La autora, que recoge para la provincia de Soria numerosos casos de renuncias a la condición de procuradores, atribuye el hecho a una lógica accitud de
} 
tanto, la reclamación progresista sobre la ampliación de la legalidad constitucional pretendía vencer cuanto antes la neutralidad política por el procedimiento de demostrar a quienes eludían responsabilidades, los avances en la consolidación del sistema parlamentario. Asimismo, la reivindicación sobre la ampliación del cuerpo electoral buscaba exclusivamente implicar en el proceso político a cuantos más propietarios mejor con la intención de aumentar la fuerza defensiva del bando liberal.

Con estos argumentos, la oposición a la política tibia de Martínez de la Rosa fue reclutando cada vez más partidarios y abrió la puerta definitivamente a la plasmación de las dos tendencias liberales. A partir de este momento, moderados y progresistas empiezan a configurar discursos y prácticas -que no suponen dos modelos excluyentes de construcción del régimen constitucional, aunque sí afectan a la estrategia política- de manera paralela y evolucionando al mismo ritmo que el propio discurrir histórico del sistema parlamentario ${ }^{10}$. Desde la dimisión de Martínez de la Rosa hasta la regencia de Espartero, las dos alternativas recorrieron un camino de progresiva definición en el que, si bien hubo constantes ocasiones para manifestar los enfrentamientos y las lu-

reserva y a la innecesaria asunción de riesgos en tiempos políticamente turbios. Véase $E l$ sufragio censitario ..., pp. 28-33. La magnitud del problema no sólo afectó a procuradores elegidos en las provincias, sino que después de constituidas las Cortes, se produjeron ausencias y deserciones en actos parlamentarios tan significativos como la discusión sobre el proyecto de contestación al discurso de la corona o la comisión formada para otorgar legalmente los derechos de sucesión legítima de Isabel II. A este respecto, Fernández de los Ríos señalaba que sen el Estamento de Próceres [...] hubo varios individuos que pretextando enfermedad o empleando orras excusas, se negaron a asistir a la discusión, temerosos de contraer compromisos o faltos de valor para dar un voto contrario a las opiniones dominantes. Nombrada la comisión, dos individuos no quisieron formar parte de ella: el arzobispo de Burgos pidió licencia para trasladarse a su dí́cesis, y el marqués de Camarasa dejó de asiscir a las sesiones; llegada la votación, se abstuvo usando de la facultad del reglamento el conde de Taboada, y no quisieron enviar por escrito su voro el conde de Atares, el arzobispo de Burgos, el atzobispo de Valladolid, el marqués de Camarasa y el de San Martín de Hombreiros». Véase Estudio bistórico de las lucbas politicas en la Espatia del siglo XIX, Vol. I, Madrid, 1880, p. 208.

${ }^{10}$ No se pretende restar importancia a las distancias entre moderados y progresistas, sino resaltar que, como miembros de una misma clase social, compartían aspiraciones semejantes y expectativas similates. Desde este punto de vista, Catmelo Romero destacaba —en el prólogo a la obra citada de CABALLERo, M.: El skfragio centitario ..., pp. 10-11- que el Parlamento fue «un órgano de discusión entre iguales que representaban a una minoría de iguales o próximos privilegiados económicamenten, teniendo en cuenta que el sufragio censitario era expresión de la coincidencia de liberales moderados y liberales progresistas en lo fundamental: la propiedad». En el mismo sentido, Juan Pro defendía la necesidad de analizar con enfoques menos esquernáticos las élites de la España liberal y argumentaba que, por ejemplo, «la organización de los partidos progresista y moderado en la España de Isabel II, parece responder en gran medida a [una] lógica de redes personales, una vez descartada la hipótesis de una adscripción socioprofesional distinta de las bases de ambos grupos; en muchas localidades moderados y progresistas eran sólo etiquetas ideológicas que recubrían facciones - ligas preexiscentes de familias notables, que venían rivalizando por el poder desde el Antiguo Régimen». Véase su artículo «Las élices de la España liberal: clases y redes en la definición del espacio social (1808-1931)», Historia Social, 21, 1995, p. 64. 
chas políticas por el poder, predominó, no obstante, un afán de unidad impuesto por la necesidad de conjurar el peligto carlista, cuya existencia era una amenaza común.

Derivada fundamentalmente de esta situación de guerra civil, la fragilidad del poder político y la quebradiza salud de los sucesivos ministerios fue una constante hasta la firma del Convenio de Vergara. Tratándose además de un estadio político primitivo, la labor del liberalismo en estos primeros años tuvo mucho de improvisación, adaptación y rectificación. La crítica siempre fue más clara que la alternativa y todo ello configuró de manera inevitable un poder vulnerable. Ningún gobierno consiguió durar en el ejercicio de su autoridad porque en esta fase experimental la política fue un constante ensayo y su práctica distaba mucho de estar rigurosamente normalizada. Los progresistas, convencidos de que una política precavida era síntoma de debilidad y alentaba, en consecuencia, a los enemigos del liberalismo, obstaculizaron la acción de los gobiernos moderados. Y los moderados, seguros de que la aplicación de medidas más radicales disuadía a posibles partidarios y aumentaba indirectamente los adeptos al carlismo, bloquearon, con el apoyo de la Corona, la gobernabilidad progresista. No obstante, y a pesar de las distancias parlamentarias, hubo ocasiones críticas en las que se produjo el consenso necesario que permitió marcar un rumbo conjunto en la defensa del constitucionalismo y que demuestra, a la vez, el interés común que moderados y progresistas compartían en cuanto a las claves esenciales del proceso de transformación liberal.

Tras la dimisión de Martínez de la Rosa y la caída del gobierno continuista de Toreno, un primer acto de unidad se produjo en torno a las medidas que Mendizábal, recién llegado al poder, aplicó para acabar con la guerra. La puesta en marcha de la desamortizacion, iniciativas como la del sistema de anticipación de fondos al Estado o proyectos como el de elaborar una nueva ley electoral, fueron algunas de las soluciones que Mendizábal intentó desarrollar con el propósito de parar la guerra y el efecto añadido de satisfacer las expectativas progresistas. Su política contribuyó de manera decisiva a incrementar la confianza en el proyecto liberal, toda vez que supo crear una red de compromisos firmes con el nuevo régimen que, poco a poco y conforme se fue haciendo más nítida la percepción de los beneficios derivados de la construcción de un sistema representativo, repercutieron en un aumento del interés político y en una mayor implicación en la defensa de la causa constitucional ${ }^{t 1}$.

"Estos resultados prácticos de la polírica seguida por Mendizábal fueron elogiados por Ramón de Santillán, que confesó después en sus memorias la intención verdadera con la que se habian puesco en marcha medidas como la anticipación de fondos. Este siscema no sólo había permirido atraer capitales con los que avituallar al ejército liberal, sino que logró el más importante propósito de implicar a los prestamistas que, para recuperar su dinero y los beneficios, no tendrían otro remedio que apoyar a sus deudores: «esta especie de juego, en que por el aliciente de grandes ganancias tomaban parte directa o indirectamente todos los capitalistas, ponía en circulación capitales que sin él habrían quedado sepultados y adhería además a nuestra causa a multitud de personas tímidas que 
Aun así, el carlismo siguió mostrando su vigor y la guerra no terminaba. En un clima de notable incertidumbre, donde las estrategias políticas tenían todavía mucho de improvisación, el discurso y la práctica estaban sujetos a continuos reacomodos, y fruto de una creciente preocupación las críticas también llegaron para Mendizábal, que tuvo que encajar notables disidencias como la de Istúriz o la de Alcalá Galiano- entre sus propias filas. La oposición a la política de Mendizábal - minoritaria, pero apoyada por la Corona- acabó finalmente con su gobierno, colmado de reproches por no concluir la guerra y acusado de abuso de poder por servirse indiscriminadamente del voto de confianza; instrumento político que le habían otorgado las Cortes para emprender sin consulta previa cuantas acciones fueran necesarias en la lucha contra la reacción.

La retirada de Mendizábal — percibida por los progresistas como una destitución- dejó paso al gabinete Istúriz, que contó, desde un principio, con una cerrada oposición por parte de la mayoría mendizabalista. Con Olózaga a la cabeza, los progresistas intentaron frustrar los planes del nuevo gobierno, cuyo nombramiento permitía adivinar los miedos de la monarquía y del núcleo más moderado a profundizar en el proceso revolucionario por la vía de las decisiones contundentes. El ascenso de Istúriz fue interpretado como un freno a las reformas de Mendizábal, lo que en definitiva hacía presagiar un nuevo retroceso político en perjuicio de las expectativas progresistas y su objetivo de aumentar los aliados del liberalismo. El gobierno de Istúriz - que, desde el voto de censura hasta la incesante y corrosiva crítica de la oposición, fue superando todas las trabas parlamentarias- cedió finalmente ante el motín de los sargentos de La Granja; colofón de la insurrección progresista, cuyos métodos basados en el levantamiento y la proclama se empezaban a vislumbrar ya, por parte del progresismo, como el único medio eficaz para alcanzar el poder ${ }^{12}$. Sustituido inmediatamente por Calatrava, los progresistas retomaron su interrumpida tarea de gobierno y asumieron de nuevo la responsabilidad de conducir el proceso de transformación.

El ministerio que surgió de los sucesos de La Granja satisfizo de inmediato las exigencias revolucionarias, aunque en esta ocasión -aleccionado por el balance de la trayectoria política- quiso transmitir desde un principio una imagen atemperada y eludir cualquier acto de provocación. Prueba de ello fue la designación retardada de Mendizábal como ministro de Hacienda. Los pro-

\footnotetext{
de otro modo hubjeran permanecido neutrales». Vease Memorias (1815-1856), Vol I, Estudio General de Navarra, Pamplona, 1960, p. 158.

${ }^{12} \mathrm{La}$ interpretación de los sucesos de La Granja en el contexto más amplio del levantamiento progresista, puede verse fundamentalmente en TUNOON DE LARA, M.: «En torno a la rebelión de los sargentos de La Granja. 1836m, en Estudios de Historia Contemporánea, Hogar del Libro, Barcelona, 1982 ( $3^{\mathrm{a}}$ ed.), pp. 11-19; y rambién en Pérez GARzón, J. S.: «Isabel II. Desartollo y consolićación de la sociedad burguesa», en DOMínguez ORTL, A.: dir., Historia de España. 9. La sransición del Antiguo al Nuevo Régimen (1789-1874), Planeta, Barcelona, 1988, pp. 328-330.
} 
gresistas le necesitaban para culminar el proceso de saneamiento hacendístico y las reformas económicas que habían quedado pendientes, pero hasta que fue oportuna su incorporación, Calatrava se valió de un sustituto provisional, Mariano Egea, con la intención de sortear cualquier obstáculo temprano al nuevo gobierno, que de seguro se iba a interponer por parte de los detractores de Mendizábal, señalado incluso como principal instigador de la rebelión de La Granja ${ }^{13}$. No obstante, y aunque con más tacto político, el nuevo ministerio se dio prisa en dar respuesta a las principales reivindicaciones exigidas en el levantamiento progresista. Anuló el Estatuto Real y dio vigencia provisional a la Constitución de Cádiz hasta que las Cortes pudieran reformar el código de 1812. Con el objetivo de abordar cuanto antes esta cuestión fundamental, fueron convocadas las elecciones de octubre de 1836 y las Cortes resultantes -después de hacer públicos los dos cometidos prioritarios de la legislatura que consistían en "el triunfo de la libertad, combatida por nuestros enemigos, y la reforma de la Constitución de $1812 »^{14}$ - pudieron iniciar enseguida la revisión del texto legal. Fue el siguiente acto de extensa conformidad en el discurrir político. Bien es cierto que las elecciones de octubre habían otorgado mayoría parlamentaria a los progresistas, pero la que acabó siendo Constitución de 1837 congregó a viejos y nuevos liberales, templados y radicales, en la empresa comúnmente alabada de ampliar los límites de la reglamentación constitucional.

Presidida por Argüelles y con Olózaga en las funciones de secretario, la comisión para la reforma de la Constitución exhibió desde el principio un talante conciliador ${ }^{15}$. Los progresistas habían aprendido de experiencias pasadas y ahora se trataba de evitar un nuevo bloqueo a la actividad legislativa que el proyecto revolucionario necesitaba desplegar con urgencia. Como requerían las circunstancias, la estrategia más conveniente para hacer avanzar el proceso de consolidación del liberalismo era conseguir un amplio acuerdo parlamentario en torno a los presupuestos constitucionales que habían de contribuir a afianzar la estructura del Estado. Así que, con el fin de evitar una inoportuna desunión que hubiera impedido hacer frente al carlismo — circunstancia capaz de retrasar

13 La interinidad de Mariano Egea se prolongó hasta el 11 de septiembre de 1836. Según Ramón de Santillán, aunque en realidad «el verdadero Ministro de Hacienda era Mendizábal», el nombramiento de Egea fue una argucia que pretendía «atenuar las sospechas que había contra Mendizábal de haber sido el promovedor de la sublevación de La Granjax. Ver Memorias ..., Vol I, p. 165.

14 Diario de Sesiones (en adelante D. S.), 27-X-1836, Apéndice tercero, p. 1.

is Los cinco miembros iniciales de la comisión fueron, además de Argüelles y Olózaga, Vicente Sancho, Joaquín $\mathbf{M}^{2}$ Ferrer y Antonio González (D. S., 5-XI-1836, p. 134). Posteriormente fueron elegidos cuatro componentes más: Pio Laborda, Pablo Torrens, Pedro Antonio Acuña y Manuel $\mathbf{M}^{\mathbf{a}}$ Acevedo (D. S., 16-XI-1836, p. 282). Sobre la composición de la comisión es iluserariva la descripción de C. Marichal, quien concluye que «el grupo representaba lo más granado de la tradición liberal [...]. Tenían un enfoque moderno y cosmopolita, quizá porque la mayoría de ellos había pasado largos años de exilio en Inglaterra o Francia, durance los cuales establecieron importantes contactos políricos y aprendieron mucho sobre los sistemas sociales y económicos de esos países». Ver Marichal, C.: La revolución liberal y los primeras partidos políticos en España: 1834-1844, Cátedras, Madrid, 1980, p. 138. 
una vez más las posibilidades de éxito del proyecto político de la burguesíala elaboración y redacción de la Constitución del 37 tuvo, en definitiva, un carácter transaccional. Sin duda, era preferible encajar algunas críticas por parte de los más exaltados doceañistas que irritar a una mayoría con ansias de moderación ${ }^{16}$. Después de algunas discusiones parlamentarias en las que no se registraron enfrentamientos destacables, la Corona sancionó la Constitución del 37, modelo político cuyos postulados básicos estaban destinados a perdurar en la historia del parlamentarismo español ${ }^{17}$. Además de dotar al régimen representativo de los anclajes necesarios para normalizar su funcionamiento, la ley constitucional acogió un nuevo sistema electoral. Como aclaró después el propio Olózaga, «la Constitución por sí sola, no puede nada si no va unida con una buena ley electoral» ${ }^{18}$. Esta vez el mecanismo fue concebido fundamentalmente como medio para desenmascarar a todos los propietarios. Los progresistas, firmes en su objetivo de aumentar los compromisos con el proyecto liberal para contrarrestar la fuerza carlista, buscaron la propiedad y trataron de integrar en el sistema - siempre dentro de los límites censitarios- a la mayor cantidad posible de ciudadanos propietarios ${ }^{19}$.

${ }^{16} \mathrm{La}$ intención produjo el efecto deseado y los propósitos de la comisión fueron, en términos generales, bien acogidos. Según Rico y Amat era preciso reconocer en los reformadores eun profundo conocimiento de la situación» y elogiar su prudencia ante el riesgo de ealentar de cualquier modo a los revoltosos en sus desorganizadores deliriosn. Véase su Historia Politica y Parlamentaria de Espa$\ddot{n} a$, Vol. III, Madrid, 1860, p. 62. En el mismo sentido se pronunció Fernández de los Ríos, aunque su testimonio aclaraba además las razones fundamentales que habían inducido a la comisión a adoptar una actitud contemporizadora: «se propusieron [...] hacer una Consticución que no fuese de partido, aceptable por progresistas y moderados, propia para que si el partido liberal había de concinuar dividido, la división estuviera siempre bajo la ley fundamental, para la cual no hubiera más que una clase de enemigos, los absolucistas; que lo eran naturales de toda institución liberal, los que por odio al siscema representativo combatían el crono de Isabel II, peleando para poner la corona en D. Carlos". Véase Estudio bistbrico de las lucbas ..., Vol. I, p. 245. También Andrés Borrego retrató años después «aquella inolvidable transacción" en la que Olozaga -a quien caracterizó como «nuestro desinteresado aliado para un fin político de interés común»- protagonizó, a su juicio, una metitoria negociación en favor del consenso: «bastará decir que éste, como secretario de la comisión de reforma, se reunía frecuentemente por la noche en mi casa [...] a cuyo local concurrieron durante estuvo en elaboración la refotma de la Constitución de 1812, los diputados D. Antonio Pérez de Meca, D. Francisco de Paula Castro y Orozco, D. Alejandro Món y D. Manuel López Santaella, a los que venía a comunicarnos Olózaga el estado de sus trabajos cerca de la comisión y de la mayoría, para llegar al anhelado resultado de que la nueva Constitución fuese aceptada por los órganos de ambos partidos; hechos los que conmemoro que no dejan lugar a duda de la nobleza, sinceridad y patriotismo que animaba en los inspiradores de la Constitución de 1837n. Véase La Torre de Babel en estado de construcción por obra común de los partidos poltiticos españoles, Madrid, 1890, pp. 38-39.

17 Sobre la Constitución de 1837, véanse los trabajos recogidos en el número monográfico de la Revista de Derecbo Politico, 20, 1983-84.

18 D. S., 5-VI-1837, p. 3.904.

19 Como es sabido, las condiciones para ser elector que finalmente estableció la ley, fueron auténticos detectores de propietarios, y el mismo texco presentado al Congreso lo recogía explícita- 
El proyecto de ley electoral, que fue elaborado por la misma comisión que había llevado a cabo la reforma constitucional, extendía la participación; aunque el aumento del censo no respondía en absoluto a un supuesto interés por parte de los progresistas en propiciar una apertura política excediendo los márgenes del sufragio censitario. Así lo expresaba el propio Olózaga que, en una de sus intervenciones parlamentarias se encargó de delimitar con claridad el significado político que tenían para el progresismo, la soberanía nacional y el derecho electoral:

«¿y qué tiene que ver la soberanía nacional con el derecho electoral? La soberanía nacional ya se ha dicho cien veces que se ha asignado sólo como un principio para contraponerlo a otro que es el de derecho divino, y como un principio por el cual se reconoce que los pueblos pueden establecer la forma de gobierno que más les convenga; pero que constituida ya una Nación, no puede tener aplicación ninguna dicho principio al régimen ordinario de la misman20.

Es notoria la conjunción de intereses que acercaba las posturas moderada y progresista, próximas en lo esencial, aunque distantes en las actitudes. No eran posiciones ideológicas incompatibles. Se trataba de dos estrategias distintas con un objetivo común, cuya fisonomía política -y esto es lo importante- no permaneció invariable, sino que fue cambiando al mismo ritmo que los propios acontecimientos históricos. Los fundamentos programáticos del liberalismo en defensa de los intereses propios de la burguesía fueron los que guiaron a moderados y progresisitas. Desde este punto de vista, es la observación de la práctica y de los comportamientos políticos en cada contexto, lo que facilita la comprensión de la realidad histórica, siempre cambiante, multidireccional y sin duda, contradictoria ${ }^{21}$.

Logrado el objetivo fundamental de aprobar la Constitución y la ley electoral -cuya aplicación práctica frenaría el avance de un enemigo común-el ambiente de colaboración política que había presidido la legislatura volvió a romperse. Cerrado el paréntesis de la concordia —impuesto por la necesidad perentoria de salvaguardar el régimen parlamentario y el sistema constitucional- prosiguió la lucha por el poder entre moderados y progresistas. Una vez más, la causa directa de los enfrentamientos iba a ser la guerra carlista, cuya

mente: «si se toma la propiedad como el signo de la aptitud electoral, es preciso buscarla en todas partes, bajo todas sus formasn. D. S., 31-V-1837, Apéndice primero, p. 3.789.

20 D. S., 2-VII- 1837 , p. 4.465.

${ }^{21}$ En este sentido, puede adaptarse a los comportamientos políticos la definición de estrategia que hacía Juan Pro en relación con las redes de relaciones sociales. Para el autor, las estrategias «no suelen ser el reflejo fiel de un plan a largo plazo, sino el resultado de una acumulación de decisiones concretas que intencan aprovechar las oportunidades que ofrece el medio a solucionar los conflictos que plantea, decisiones que se toman bajo condiciones de incertidumbre y de racionalidad limicada». Ver «Las élites de la España ...», p. 68. 
resistencia ante el fracaso continuado de las medidas para acabar con ella, había generalizado, como describe Rico y Amat, la impaciencia política:

«El gobierno [...] contaba como único y principal medio de poner fin a tan desoladora y continuada lucha, con la cooperación franca, pronta y en grande escala de las potencias amigas. Inglaterra con buenas palabras no proporcionaba recursos $[\ldots .$.$] . Francia era únicamente quien podía ayudar al gobierno en tan colo-$ sal empresa; pero desde la caída de Thiers, veía aquel más que nunca frustrada su esperanza. El nuevo jefe del gabinete francés, Mr. Molé, [...] anunció su negativa [y] esta rotunda declaración del gabinete francés desalentó a las fracciones del bando liberal; a los moderados, que anhelaban la intervención, o como se decía entonces la cooperación extranjera, para vencer primero a los carlistas y anular después a los demagogos; a los exaltados que temían no poder terminar la guerra con los propios recursos, y deseaban la paz para ir estableciendo sus populares reformas»22.

Los moderados pensaron que la evasiva tenía que ver con la desconfianza del gobierno francés en el ministerio español. Según Borrego, «la apetecida cooperación, no se creía que la concediese el Rey Luis Felipe a gabinetes progresistas, peto se tenía la esperanza de que la otorgase a un gabinete conservador» ${ }^{23}$. A esta convicción aún vino a sumarse el creciente malestar en las filas de la oposición desde que el gobierno comunicara oficialmente la prolongación de la actividad legislativa de las Cortes en tanto no quedaran constituidas las próximas; propósito que fue interpretado como una infracción de la Constitución recién aprobada, en virtud de la cual «lo lógico» hubiera sido - así lo pensaba Rico y Amat - disolver las Cortes y uno seguir legislando un día siquiera después de publicado" el texto legal ${ }^{24}$. Cargada, por lo tanto, de argumentos políticos, la oposición moderada consiguió derrotar al gobierno de Calatrava, y en medio de una profunda crisis ministerial - cuya resolución no quiso aceptar Espartero ni, en un principio, tampoco Eusebio Bardají-, fueron celebradas las elecciones de octubre del 37 cuyo resultado acabó favoreciendo a los moderados ${ }^{25}$.

Mejor organizados y con mayoría parlamentaria, los moderados iniciaron su turno en el poder con un breve mandato de Bardají, que sirvió de preámbulo al gobierno del conde de Ofalia; figura de mayor prestigio cuya experiencia polí-

22 Rico Y AMAT, J.: Historia Politica ..., Vol. III, p. 82.

23 BORREGo, A.: La Torre de Babel ..., p. 41.

24 Ruco y Amat, J.: Historia Polltica ..., Vol. III, p. 83.

${ }^{25}$ El resultado de estas elecciones sorprendió a los propios contemporáneos. Por ejemplo, Andrés Borrego - a quien, no obstante, alguna parte le cupo en la victoria moderada desde la divulgación de su doctrinario Manual Electoral - calificó la derrota de los progresistas de fenómeno apocas veces visto», teniendo en cuenta que "el partido progresista» era "dueño del poder $y$ de codas las posiciones oficiales, apoyado en la milicia nacional, en los ayuntamientos y dipuraciones provinciales, que en masa le pertenecían y eran las autoridades que exclusivamente intervenían en las elecciones». Véase Ensayo sobre los partidos en Evpaña, Madrid, 1884, p. 43. 
tica venía avalada por su pasado como ministro de Fernando VII. La nueva mayoría no asustó a los progresistas, que ya habían demostrado al redactar la Constitución sus intenciones conciliadoras. Pero el nombramiento de un antiguo colaborador del absolutismo como jefe del gobierno, hirió profundamente la sensibilidad política del progresismo, que temió el retorno de viejas fórmulas reformistas más preocupadas por mantener el orden que por acelerar el ritmo del proyecto revolucionario. La presión progresista obstruyó la acción del gobierno de Ofalia, de su sustituto el duque de Frías y del siguiente recambio moderado, Pérez de Castro, obligado este último a disolver las Cortes y convocar elecciones después de enfrentarse sin éxito al voto de censura presentado por la oposición. Los comicios de julio del 39 dieron mayoría parlamentaria a los progresistas, pero la firma del Convenio de Vergara, que coincidió con el inicio de la legislatura y ponía el tan deseado fin a la guerra carlista, fue capaz de amortiguar la crispación política, al menos en un primer momento.

La buena noticia enseguida dejó paso a un nuevo episodio de alteración política. Desembarazado del lastre reaccionario, el liberalismo tenía, por primera vez en lo que se llevaba de siglo, el camino libre y la oportunidad más clara para desarrollar sus principios programáticos. Guiados por esta visión política, los progresistas empezaron a exigir al gobierno de Pérez de Castro una mejor y más rápida gestión en favor del asentamiento del régimen parlamentario. Ahora, puesto que el enemigo había sido abatido, la práctica política no precisaba - según su percepción - ni extremada prudencia ni ambigüedades tácticas. Ante la incapacidad del gobierno moderado para dar solución a las reclamaciones, la oposición forzó la disolución de las Cortes y Pérez de Castro tuvo que convocar elecciones.

En enero de 1840 y como resultado de una rigurosa organización, los moderados se hicieron con el triunfo electoral. Respaldados por una sólida mayoría parlamentaria, creyeron que la nueva situación disminuiría la ansiedad política de los progresistas y permitiría, de paso, abordar cuestiones fundamentales encaminadas ya no a consolidar la estructura del Estado liberal - prueba recientemente superada - sino a dejar asegurada la dirección política de su mando. Esta ambición fue la que llevó a los moderados a presentar el proyecto de ley de Ayuntamientos, cuya discusión parlamentaria resultó ser la antesala de la revolución del 40. La modificación de la ley municipal de 1823 había sido aplazada por todos los gobiernos precedentes. La tarea más urgente de dedicar los esfuerzos a liquidar la guerra civil, desvió la atención legislativa de cualquier otro asunto. No por casualidad, a la altura de abril de 1840 , despejado el horizonte de incertidumbres políticas y con el suficiente apoyo parlamentario, los modetados abrieron el debate. El proyecto de ley contemplaba, entre otras medidas, la elección de los alcaldes por los jefes políticos, lo que en la práctica suponía un nombramiento gubernamental por vía directa. La oposición progresista, en cambio, se mostraba partidaria de la elección vecinal, pero en su propuesta no pesaba la anacrónica idea de procurar la democratización progresiva 
de la vida política ni tampoco la romántica consideración de preservar la lealtad al espíritu gaditano como insignia de su pensamiento político. Lo que estaba en juego era el manejo del poder local, pieza clave del engranaje electoral. Los progresistas no podían aceptar una ley que anulaba todas sus posibilidades de aumentar el control sobre la oligarquía local, cuya fidelidad a unos u otros mediadores era decisiva para asentar una trama caciquil de la que dependía en última instancia el ejercicio del poder político. La autoridad municipal era un instrumento determinante en los procesos electorales y los progresistas sabian que imponer alcaldes obedientes a los candidatos moderados equivalía a obtener en las elecciones triunfos moderados. Sin concesión posible en un tema de tan señalada trascendencia, la minoría progresista — con Olózaga como portavoz - recurrió al argumento de la insconstitucionalidad, aunque todos los recursos fueron pocos y, por fin, el Congreso aprobó una autorización al gobierno que le permitía, en tanto la reina sancionara la nueva ley, reorganizar los ayuntamientos conforme al proyecto discutido, documento que finalmente no recogió ninguna de las más de cien enmiendas presentadas por los progresistas ${ }^{26}$.

Otro podía haber sido el rumbo político de los acontecimientos de no contar el progresismo en estos momentos con el más prestigioso de los aliados. Espartero, el laureado militar engalonado con el reconocimiento de todos los méritos patrióticos por haber conjurado el mal carlista, decidió participar activamente en la batalla política del lado progresista, posición que el general ya había hecho pública en el manifiesto de Mas de las Matas y que no era en absoluto una inclinación espontánea ${ }^{27}$. Cuando el progresismo se negó a admitir la implantación de la ley de Ayuntamientos y alertó a sus seguidores de la burla

${ }_{26}$ Una explicación sobre la ley de Ayuntamientos de 1840 y el conflicto políico que la acompaño, en CASTRO, C. de: La revolución liberal y las municipios eppañoles, Alianza, Madrid, 1979, pp. 154160; y más recientemente PÉrez NúNEzz, J.: aLos debates parlamentarios de la ley municipal de 1840", Revista de Estudias Politicos (Nueva Epoca), 93, 1996, pp. 273-291.

${ }^{27}$ En la filiación política de Espartero tuvo una influencia considerable su matrimonio con Jacinta Martínez de Sicilia y Santa Cruz, nieta del banquero riojano Domingo Santa Cruz y sobrina del diputado progresista Francisco Javier Santa Cruz. Según Francisco Bermejo -aucor de una tesis doctoral reciente en la que ha abordado una rigurosa invescigación sobre los años riojanos de Espartero- «sería muy difícil entender el futuro del Capitán General, Duque y Regente del Reino sin el ambiente político vivido en la residencia de los Santa Cruz logroñeses». Cuando en 1827 el militar entroncó, por vía nupcial, con la familia Santa Cruz, ingreso al mismo tiempo en un «lobby familiars -_así lo denomina Francisco Bermejo después de analizar con extraordinaria minuciosidad los negocios y actividades de todos los miembros del clan- de considerables proporciones económicas, que, además, obstentaba la representación máxima del progresismo riojano. Sobre este interesante $-\mathrm{y}$ hasta ahora desconocido- aspecto de la vida de Esparteto, véase la tesis doctoral inédita de BERMEJo, F.: Espartero. Hacendado riojano, defendida en la Universidad de La Rioja el 19 de diciembre de 1997. Aprovecho la ocasión para agradecer muy sinceramente al autor la consulta del trabajo, así como la generosa disposición y constante ayuda que me viene prestando en la elaboración de la investigación sobre Olózaga que, por la afinidad con el tema de Espartero y las élites riojanas, se está beneficiando de la nada común hontadez intelectual que le caracteriza.

Hispania, LX/2, núm. 205 (2000) 623-672 
constitucional que suponía el proyecto moderado, no desaprovechó la colaboración de Espartero - apoyo que quiso presentar como garantía de la legitimidad de sus aspiraciones - para ejercer una presión calculada contra la que poco podían hacer los moderados, conscientes de que el militar era - como indicaba Rico y Amat-- "un formidable enemigo" al que "no se podía combatir de frente por escudarle con su protección y confianza la reina gobernadora» ${ }^{28}$. Asumiendo el liderazgo del progresismo y haciendo valer su influencia sobre María Cristina, Espartero desaconsejó a la reina ratificar la ley municipal. A pesar de las advertencias, su gestión no tuvo éxito. La reina firmó y la sanción de la ley precipitó el levantamiento revolucionario que puso fin a su regencia. Con Espartero aclamado en Barcelona por la multitud y la defensa de la Constitución del 37 como lema, los progresistas organizaron, una vez más, el movimiento juntista. María Cristina se vio obligada a dimitir y el 12 de octubre abandonó el país dejando vía libre a tres años de gobierno progresista.

\section{LOS RETOS DEL PROGRESISMO DURANTE LA REGENCIA DE ESPARTERO Y LOS ACONTECIMIENTOS HISTÓRICOS QUE PRECEDIERON LA FORMACIÓN DEL GO- BIERNO OLÓZAGa.}

La regencia fue ocupada provisionalmente por Espartero, el artífice de la pacificación del país y la figura que había contribuido a dar lustre al progresismo con su soberbio prestigio. Disueltas las juntas y convocadas las elecciones de febrero de 1841 que favorecieron a los progresistas - beneficiarios a su vez del retraimiento electoral practicado por los moderados en señal de protesta por los recientes acontecimientos-, la normalización de la vida política parecía fácil de restablecer y la aceleración del programa revolucionario no tenía obstáculos a la vista. Sin embargo, una vez más vino a enturbiarse la situación y esta vez fue en el propio seno del progresismo donde empezó a madurar la semilla de la discordia.

En la interpretación de los comportamientos políticos es necesario tener en cuenta además de la evolución propia de las posturas iniciales - cuya característica intrínseca es la variabilidad y nunca el inmovilismo-, la influencia de la experiencia acumulada, del análisis de las posibilidades políticas, de la necesidad de readaptar discursos a realidades, e incluso, del papel que desempeña la improvisación; aportaciones adicionales que enriquecen, completan y acaban condicionando respuestas políticas distintas en cada momento histórico concreto. El progresismo - como tampoco el liberalismo del 12, del 20 o del 34 fue lo mismo- no era una actitud invariable y unívoca sino que, permeable al discurrir histórico, fue incorporando en su trayectoria experiencias diversas en virtud de las cuales su dicurso se vio alterado tanto como fue preciso. Esta rea-

${ }_{28}^{2 B}$ Rico y Amat, J.: Historia Polftica ..., Vol. III, p. 201. 
lidad - tachada en ocasiones de contradictoria como si tal condición no fuera asumible - lejos de desvituar su identidad, formó parte de su propia definición política.

Andando ese camino sinuoso y condicionado por los avatares históricos, el progresismo a la altura de 1841 tuvo que dar nuevas respuestas a problemas nuevos. El primero de ellos fue el debate sobre la regencia única o compartida. La colaboración de Espartero no había sido cuestionada mientras fue necesaria, pero después de triunfar la revolución del 40 , en las filas progresistas había dos opiniones enfrentadas en torno a la figura del militar. Los partidarios de formar una tegencia tripartita temían la ambición de Espartero cuyo mando exclusivo podía derivar en una dictadura personal. Por el contrario, quienes defendían la regencia única se apoyaban en la necesidad de establecer un poder fuerte, capaz de garantizar un periodo de estabilidad que permitiera consolidar las conquistas adquiridas; estabilidad que la ambición y otros vicios del poder arruinarían si se compartía la autoridad. Pero detrás de la oratoria parlamentaria se escondían los verdaderos argumentos políticos. La militancia progresista comenzó a dividirse entre una mayoría de trinitarios agrupados alrededor de Fermín Caballero y Joaquín María López, y una minoría de unitarios, dirigidos precisamente por Olózaga - ministro plenipotenciario en París - y Cortina - ministro de la Gobernación-; agentes del gobierno y criaturas de Espartero, que debían al regente los más importantes trofeos de su carrera política.

Quebrada la afinidad progresista, triunfó por fin la opción unitaria y las Cortes eligieron a Espartero regente del reino. Con el mítico general en el poder y barrida la oposición moderada, el progresismo volvía a conducir el proceso de transformación y esta vez con la máxima autoridad a su favor. Sin embargo, entre sus dirigentes había aparecido la división y aún tendrían que contar con la reorganización de los moderados, cuya estrategia para recuperar el poder empezó a trazarse de inmediato. Desde el exilio, alrededor de María Cristina y con el apoyo de la monarquía francesa, el objetivo se centró en derrotar a Espartero con la intención de recuperar la regencia usurpada y dejar huérfano al partido progresista. La conspiración planeada desde el otro lado de la frontera tuvo su primer episodio en la sublevación de la Guardia Real en Madrid; levantamiento que, pese a que Espartero logró reprimir, significó a la larga el principio de su derrota ${ }^{29}$. En previsión de las consecuencias que pudiera

29 Olózaga, embajador en París, fue el encargado de vigilar los movimientos de los sediciosos, y su actividad diplomárica para frustrar los planes conspirativos resultó determinante. Algunas de sus gestiones para lograr información, en CONDESA DE MINA: Memorias, Tebas, Madrid, 1977, pp. 233-234; o también en FERNANDEZ de LOS Ríos: Olbzaga ..., p. 344; y la carta que envió a María Cristina exigiendo su pronunciamiento para desacreditar la insurrección, en BERMEJO, I. A.: La Estafeta de Palacio. Historia del reinado de lsabel II, Madrid, 1872 (2 ed.), Vol. I, pp. 159-160. El patriótico comportamiento del embajdor fue recompensado por Espartero con la Gran Cruz de Carlos III, condecoración que Olózaga rechazó alegando que no quería causar a su provincia los «inconvenientes y molestias de una eleccion parcialm. $Y$ es que, para evitar corrupciones y asegurar 
tener el pronunciamiento moderado de octubre, algunas juntas volvieron a reunirse para respaldar al gobierno y hacer frente a los reaccionarios. Sofocada la rebelión, Espartero mandó disolverlas, pero la de Barcelona se resistió a cumplir la orden. Era el primer aviso de descontento con el gobierno progresista y con la autoridad de Espartero. Cuando al año siguiente se debatió en el Congreso la conveniencia para los intereses industriales del proteccionismo o el librecambio, en Barcelona estalló el conflicto. Al regente, acusado por los catalanes de defender el librecambismo, sólo se le ocurrió, para restituir el orden público, bombardear la ciudad. El excelso general, vitoreado no hacía mucho tiempo, fue criticado por lo excesivo del castigo y su imagen política empezó a deteriorarse vertiginosamente.

Además, la polémica en torno al proteccionismo terminó de dividir a los progresistas. Aunque el desacuerdo venía de lejos, aquella discusión acabó en voto de censura y anunció la escisión del progresismo, que sólo se mantuvo unido para provocar la caída del gabinete González, forzado a dimitir cuando a finales de mayo el resultado de la votación demostró que no tenía el apoyo de la Cámara. Liquidado el primer gobierno de Espartero, los progresistas recuperaron el pulso de la discordia y el bombardeo de Barcelona vino a aumentar la tensión en medio de la crisis interna. El regente no tenía más apoyo que el de sus nuevos ministros, los ayacuchos, presididos por el marqués de Rodil. Mientras, los puros Joaquín María López y Fermín Caballero, dirigieron una campaña de acoso contra el duque de la Victoria, a quien veían más preocupado por mantener el orden público con modales autoritarios que por amparar un verdadero avance del programa político que reivindicó la revolución de septiembre de 1840. Por último, los progresistas legales, Cortina y Olózaga, empezaron a abandonar su antigua filiación esparterista, decepcionados por los métodos represivos del regente y, en opinión de algunos contemporáneos, frustrados por no haber obtenido su confianza para relevar al ministerio de González ${ }^{30}$. El discurso de los legales, suavizado y ante todo práctico, representaba la sensatez política de quienes ya habían tenido responsabilidades de gobierno, pero Espartero prefirió no respaldar ninguna de las dos opciones progresistas y buscando

\footnotetext{
la independencia política, el artículo 43 de la Constitución del 37 declaraba sometidos a reelección a los diputados y senadores que admitieran del gobierno o de la Casa Real pensión, empleo, comisión con sueldo, honores o condecoraciones. En virtud de la incompatibilidad que le afectaba, Olbzaga manifestó su preferencia por el acra de diputado; distinción que le imporcaba mucho más de cara a consolidar su feudo político en Logroño, terreno conquistado cuyo mando caciquil no debía ceder a otro interesado. Así lo hizo constar en su renuncia al galardón, dirigida a Antonio González, Presidente del Consejo de Ministros: «V. E. no extrañará que no acepte ahora una condecoración que había de causar a mi provincia los inconvenientes y molestias de una elección parcial, por más grato que me fuera recibir este honor del Gobierno de S. M., y acaso la renovación de la confianza con que la provincia de Logroño me distingue siempre nombrándome su Diputado a Cortes». Archivo del Ministerio de AA.EE., Personal, leg. P-178, exp. 9.588.

30 Véase, sobre todo, RIco Y AMAT, J.: Historia Politica ..., Vol. III, pp. 339-340.
} 
la neutralidad, formó un gabinete ecléctico y sin personalidad. Aquella decisión, según Rico y Amat, resultó ser un grave error político que no resolvió la división y contribuyó a aumentar el desprestigio de Espartero:

«Bien conocemos que no cabía por entonces avenencia entre el regente, hombre de progreso templado, y la parcialidad exaltada [...], pero de sus ideas templadas a las que constituían la política de Olózaga y Cortina no mediaba gran diferencia. Espartero, pues, debió entregarles el poder y formar de ese modo un partido numeroso y compacto, reuniendo en derredor de sí todos los elementos de orden y de racional reforma que encerraba el partido progresista. Intentó en realidad Espartero esa reconciliación; pero fuese por falta de tacto en las negociaciones, bien por los estudiados desdenes de Olózaga, tan aficionado siempre a coquetear con las situaciones políticas, lo cierto es que [...] no pudo encontrat hombres de talento y de prestigio, y tuvo que echarse otra vez en manos de sus particulares amigos, nombrando un ministerio débil, antipático e inútil completamente para gobernar en tan difíciles circunstancias. Como era natural, estos nombramientos aumentaron el descontento de los oposicionistas que, en desacuerdo aún entre sí, suspendieron los ataques, próximas ya a cerrarse las sesiones del Congreso, remitiendo a la nueva reunión de los cuerpos deliberantes la fácil obra de derribar a un ministerio incapaz»31.

Efectivamente, Espartero había disuelto las Cortes a su regreso de Cataluña y convoc6 elecciones para matzo del 43. Los progresistas, conscientes de que estos momentos turbulentos estaban dando motivos a los moderados para reorganizarse, intentaron contribuir a la gobernabilidad con cierta esperanza de que en una nueva legislatura y una vez removido el último ejecutivo, se pudiera recomponer la situación. Sin embargo, después de las elecciones de marzo no sólo no se aclaró el panorama, sino que se complicaron más las cosas. Los progresistas seguían divididos, un número considerable de moderados había vuelto al Congreso y, por si fuera poco, algunos republicanos debutaban, aunque todavía con un ideario impreciso, en la escena parlamentaria ${ }^{32}$. A las pocas semanas de la apertura de las Cortes, el marqués de Rodil y sus ministros dimitieron, acorralados por tanta y tan variada oposición. Espartero, para «rehabilitarse a los ojos de los progresistas", como interpretaba Rico, confió entonces en

31 Ibid., p. 340. También Fernández de los Ríos alude a las negociaciones entre Espartero y Olózaga para buscar un gobierno acorde con las circunstancias, pero atribuye el fracaso de aquellas a la actitud «impertinente» de Antonio González, que se inventó una autorización del regente para encargarse de formar un gabinete. Olózaga, molesto por el malentendido, se autoexcluyó de las conversaciones y Espartero para tratat de tecuperar su colaboración le envió una nota que, según Fernández de los Ríos, decía: «Es Vd. un niño: no creí que me dejara Vd. solo en tales circunstancias; venga Vd.; la patria lo exige y se lo pide Baldomero Esparterom. Ver Ol6zaga ..., p. 329.

32 Sobre la actividad republicana en estos años y su orientación política, véase CAsTro ALFín, D.: «Orígenes y primeras etapas del republicanismo en Españan, en TowNSON, N.: ed., El republicanismo en España (1830-1977), Alianza, Madrid, 1994, pp. 42-49. 
los puros y formó un gobierno dirigido por Joaquín María López y con Fermín Caballero en el ministerio de la Gobernación ${ }^{33}$. Pero el conocido como ministerio de 9 de mayo no duró ni un mes. López intentó limitar el poder del general Linaje y Espartero, al no admitir que se apartara del cargo al que era su íntimo amigo y fiel colaborador, provocó la dimisión del gabinete después de diez días de gobierno ${ }^{34}$. Enterado el Congreso de la decisión, Olózaga dio su apoyo a López y al grito de iDios salve al país! iDios salve a la Reina! arremetió contra Espartero pronunciando el discurso más famoso de toda su carrera política:

«iAy del país, señores, que se entrega en manos de hombres de ánimo turbado, de consejeros trémulos! y iay también, señores, del Regente que siga consejos imprudentes en circunstancias tan críticas! [...] Un estorbo, señores, se ha puesto entre el Regente y el país, y ese estorbo es un hombre [Linaje] cuya destitución habían propuesto los Ministros pasados. Aquí se presenta un dilema terrible: escoja el Regente, señores, escoja el Regente entre ese hombre y la Nación entera representada en el Congreso unánime de sus Diputados. [...] Después de esto, cualquiera que sea nuestra suerte, particular o privada, retirémonos tranquilos; donde quiera que nos vean nuestros comitentes dirán: ahí va un representante digno, independiente y enérgico que merece ser enviado cien veces a representar esta gran Nación que tiene que salvarse de tantos peligros. iDios la salve, señores, y salve a nuestra Reina!»35.

Espartero se quedaba sin apoyos. El regente nombró a Gómez Becerra presidente de un nuevo gobierno, pero sólo logró mantenerse en el poder hasta julio. El discurso de Olózaga había conseguido unir a todos los detractores de Espartero bajo el único lema de acabar con su autoridad. Toda la oposición antiesparterista, coaligada estratégicamente, se pronunció a partir de julio recurriendo una vez más al movimiento juntista para reclamar el regreso de Ló-

${ }^{33}$ Rico y Amat, J.: Historia Politica ..., Vol. III, p. 363. Sobre la presidencia de López y su relación política con el progresismo, véase el trabajo de MOLINER PrADA, A.: Joaquin María López y el Partido Progresista, 1834-1843, Instituto Juan Gil-Albert, Alicante, 1988; y también SANTOS, R: «El pensamiento progresista de Joaquín María López», Revista Internacional de Sociología, Tomo XII, $\mathrm{n}^{\circ} 46,1983$, pp. $125-166$.

34 Fuentes impresas retrataron al general Francisco Linaje como un aguerrido militar que «llegó a encumbrarse hasta ser el alma de [...] D. Baldometo Esparterom. Fueron conocidas sus dotes con la pluma que puso siempte al servicio de Espartero como secretario personal. Angelon asegura que sus sensatos consejos influyeron en más de una ocasión sobre las decisiones del regente y a Linaje se le atribuye la redacción del manifiesto de Mas de las Matas. Véase ANGELON, M.: Isabel II. Historia de la Reina de España, Barcelona, 1860, pp. 220-222. El enfrentamiento entre el gobietno y Espartero fue descrito con todos los detalles por el propio LÓPEZ, J. M.: Exposición razonada de los principales sucesos políticos que tuvieron lugar en España durante el Ministerio de 9 de Mayo de 1843 y después en el Gobiemo Provisional, Madrid, 1857, pp. 21-23.

${ }_{35}$ D. S., 20-V-1843, pp. 509-510. Según N. Pastor Díaz, a partir de la célebre frase, Olózaga fue llamado el Mirabeau español. Ver «D. Salustiano de Olózaga», en Galería de españoles celebres contemporáneos, Vol. V, Madrid, 1844, p. 26. 
pez. El regente aún intentó defenderse con las armas, pero Narváez se enfrentó al ejército esparterista y puso fin a su desesperada agonía en Torrejón de Ardoz. Las puertas de Madrid se abrieron para aclamar a Narváez y Espartero tuvo que abandonar la regencia. El día 23 de julio Joaquín María López volvió a hacerse cargo de un gobierno provisional, mientras el ex-regente preparaba su viaje hacia el exilio.

El nuevo gobierno recuperó a señalados progresistas, que ya habían formado parte del ejecutivo anterior, como Fermín Caballero o el general Serrano; este último, ministro universal mientras duró la irregularidad política. Pero la participación de los moderados en el levantamiento y en la coalición había permitido la integración en las juntas de elementos reaccionarios que, como Narváez - recién ascendido a capitán general del distrito de Madrid- acabaron asumiendo el mando del poder militar. Serios inconvenientes acarrearía al progresismo la intrusión del general que, en cuanto le fue posible, se hizo con el control de los principales puestos del ejército colocando en ellos a sus adláteres. Ramón María Narváez era la fuerza militar que les había faltado a los moderados, pero a partir de ahora su infiltración en el progresismo - que en principio no desconfió del general toda vez que había quedado bien demostrada su inclinación antiesparterista - iba a dar muy buenos resultados ${ }^{36}$.

Con el enemigo en casa, el ministerio de López servía a los propósitos moderados, cuya estrategia para alcanzar el poder se basaba en la combinación del ritmo lento y la astucia política. A ello contribuyeron las primeras decisiones del gobierno provisional que fueron airadamente contestadas por buena parte de los progresistas. López disolvió el Ayuntamiento de Madrid y la Diputación de la provincia, hizo lo propio con el Senado y convocó elecciones para el 15 de octubre. Pero el escollo más difícil fue el desarme de la Milicia de Madrid, decretado por el ministro de la Gobernación, Fermín Caballero, que fue interpretado como una traición a los principios progresistas siempre defendidos con particular énfasis por los milicianos entre los cuales primaba, además, esa misma tendencia política. A la decepción provocada por las primeras soluciones del gobierno provisional, vino a sumarse el descontento de la junta de Barcelona que seguía organizada esperando el cumplimiento de la promesa del general Serrano, ahora ministro de la Guerra. Durante la insurrección antiesparterista Serrano había anunciado la creación de una Junta Central en Madrid que, con el objetivo de encauzar políticamente el movimiento, daría salida a las reivindicaciones ciudadanas. Con la disculpa de que ninguna otra junta apoyaba la iniciativa después del triunfo del levantamiento, el compromiso no se llegó a verificar y en Barcelona creció la insatisfacción y se extendió la insubordinación al gobierno de Madrid. La organización de la capital catalana acabó autodeno-

${ }_{36}$ El mismo López confesó su confianza en el militar que había correspondido al nombramiento de general con la promesa de «la adhesión más sincera y profunda a la Constitución del Estadow. Véase LOPEZ, J. M $\mathbf{M}^{\mathrm{a}} .:$ Exposición razonada ..., p. 90. 
minándose Junta Suprema y a ella se agregaron movimientos centralistas que habían ido prendiendo en otros puntos de la región. Para enfriar la exaltación, el gobierno de López envió a Barcelona al general Prim que, dada su popularidad entre los catalanes, era el único interlocutor adecuado para dirigir una posible negociación. Prim no tuvo éxito y el desacato de los catalanes fue contestado con un nuevo bombardeo sobre Barcelona; extremada medida que avivó la revuelta y prolongó su duración hasta mediados del mes de noviembre ${ }^{37}$.

En esta difícil coyuntura política y con focos rebeldes dispersos que mantenían la estela revolucionaria de las juntas, se celebraron las elecciones de octubre. En la nueva legislatura, con las fuerzas políticas más igualadas que en febrero, se quiso transmitir desde un principio el deseo compartido por la mayoría de ordenar y pacificar la situación creada. La revolución permanente y el desorden público no favorecían los intereses comunes de la burguesía y corregir las desviaciones que podían poner en peligro sus planes era tarea prioritaria. En este sentido, resultaba de extremada urgencia volver a colocar la pieza fundamental del sistema y enseguida se planteó la cuestión de la mayoría de edad de la joven Isabel. Cubrir oficialmente el vacío de poder era un propósito unánime y, por lo tanto, ni en el Congreso ni en el Senado hubo el menor inconveniente para proclamar reina a Isabel II, a pesar de que fue necesario desatender el texto constitucional para adelantar la edad que le permitiría ocupar el trono desde que el 10 de noviembre juró la Constitución. El asunto, no obstante, se había ventilado tiempo antes. En medio del fragor revolucionario que persistió después de la caída de Espartero, los moderados, con Narváez a la cabeza, llamaron la atención del gobierno provisional sobre la conveniencia de restituir el poder desocupado del ex-regente. El 8 de agosto, en el Palacio Real y teniendo por testigos a altas dignidades, Joaquín María López formalizó delante de la futura reina el compromiso de declarar su mayoría de edad en cuanto se iniciara la nueva legislatura. El solemne acto sirvió para excitar los ánimos de los juntistas barceloneses y arreciaron las críticas de otros muchos progresistas radicales que tacharon al gobierno de prepotente por pactar acuerdos anticipándose a la apertura de las Cortes. A pesar de los recelos, la declaración de Isabel II como reina de España se llevó a cabo tal y como había sido prevista. Despejada la duda que afectaba a la piedra angular del régimen constitucional, los moderados ya podían preparar con garantías su maniobra política para recuperar el poder. El gobierno de López fue ratificado por la recién estrenada reina, abandonando así su carácter provisional, pero no acompañó el optimismo a la legitimación del gabinete que, además de la persistente crisis catalana, pronto tuvo que encarar nuevas dificultades.

${ }^{37}$ Un relato pormenotizado de los acontecimientos en LAFUtNTE, M.: Historia General de Espafia desde los tiempos primitivos basta la muerte de Fernando VII. Continuada basta nuertros días por Juan Valera, Barcelona, 1890, Tomo XXII, pp. 388-391. 
Dividir a los progresistas formaba parte de la estrategia moderada y la primera oportunidad para utilizar la táctica llegó con motivo de la elección de presidente del Congreso. Los progresistas propusieron a Cortina y a Cantero, y los moderados, en lugar de presentar una alternatiya coincidente con su alineación política, defendieron la candidatura de Olózaga. Sin duda, se trataba de sembrar cizaña en el seno del progresismo, que empezaría a discutir acerca del comportamiento de su portavoz. Prestarse al juego de los moderados era algo insólito en la conducta del intachable progresista y, efectivamente, entre los miembros de su partido - jaleados por los más desafectos a su persona, que nunca perdonaron su participación en la caída de Espartero- fue calando la sospecha de que Olózaga buscaba llegar al poder con más ambición que escrúpulos. Quienes presuponían tal actitud se vieron reforzados por los rumores que se difundieron acerca de una reunión, previa a la elección de presidente del Congreso, en la que algunos moderados habrían decidido promover un amplio respaldo para un posible gobierno presidido por Olózaga y en el que pudieran encajar algunos de sus partidarios como Mazarredo o Pidal ${ }^{38}$. El hecho es que, valiéndose del carismático Olózaga, los moderados iban dando pasos certeros, mientras los progresistas desagregaban sus fuerzas. La votación en la Cámara benefició a Olózaga en segunda vuelta y, por 66 votos de los 118 emitidos, fue nombrado presidente del Congreso ${ }^{39}$. La desunión en el seno del progresismo ya había cundido y los resultados de la votación para ocupar la presidencia del Congreso acababan de revelar la ruptura de la armonía parlamentaria con la que se inició la legislatura.

La nueva situación provocó en el gobierno progresista una profunda incomodidad y la crisis se agudizó por el atentado que sufrió Narváez el 6 de noviembre en las calles de Madrid. Fuera una emboscada con tintes subversivos o un simulacro de los moderados para poder amplificar la magnitud de los desórdenes, el suceso sirvió de coartada para que el militar impusiera una política represiva, Llegando incluso a cerrar el Eco del Comercio ${ }^{40}$. El ministro de la Gobernación, Fermín Caballero, como respuesta a la que ya era una clara ex-

3a Posteriormente, José de Posada confirnó en el Congreso la propuesta de aquel pacto y el ofrecimiento de los moderados para que, a cambio de "nada absolutamente", Olózaga "gobernase el país y le diese orden y paz”. D. S., 7-XII-1843, p. 425. Sobre el fundamento de estas conversaciones, véase también MARichaL, C.: La revolución liberal ...., p. 260.

${ }^{39}$ D. S., 4-XI-1843, p. 1 14. Para la importancia de la presidencia como einstitución decisoria en la vida política» y órgano parlamentario de los gobiernos, véase SEvilLA ANDRÉs, D.: «La Presidencia del Congreso de los Diputados (1810-1936)", Revista del lnstituto de Ciencias Sociales, $\mathrm{n}^{\circ}$ 14, 1969, pp. 21-56.

40 Narváez ya había manifestado con anterioridad su vocación represora y la urgencia de actuar en favor del orden. Según Joaquín María López, el general hablaba constanremente en los consejos de ministros de conspiraciones y uproyectos de asesinato, así contra su persona, como contra las del gobierno". Con aquella disculpa, proponía - añadía López-- «asegurar a los sospechosos, [...] allanar y reconocer el domicilio, y adoprar otras medidas que la ley fundamental ponía muy fuera de nuestro alcance». Citado en LAFUENTE, M.: Hissoria General de España ..., Tomo XXII, p. 386. 
presión antiprogresista, aceptó el desafio a su gobierno proponiendo reorganizar la Milicia y preparar las elecciones municipales. Ambas medidas iban a culminar el plan de los moderados, que ya no tenían ninguna duda sobre la necesidad de deshacerse de aquel gobierno. Ante la presión insoportable, Joaquín María López propuso a la joven reina la sustitución de su gabinete y, como él mismo dejó escrito, le recomendó formar uno nuevo bajo la dirección de Olózaga; cuya personalidad —así se había demostrado en la votación para presidente del Congreso - contaba, al fin y al cabo, con apoyo parlamentario:

«No nos prestamos a continuar sino por los pocos días que se necesitasen para organizar el nuevo gabinete, y a este fin nos reservamos aconsejar a S. M., como lo hicimos, la persona a quien convenía encargar esta ardua y dificil misión. Indicamos al Sr. Olózaga, diputado del partido progresista, que a la sazón era presidente del Congreso, y al obrar así mostramos nuestro ciego respeto a las prácticas parlamentarias».

Además de la fidelidad a los principios parlamentarios, López tenía motivos de mayor peso para que su puesto fuera ocupado por Olózaga:

«y además [mostramos] el mas vivo interés por el partido del progreso a que todos los ministros pertenecíamos, sin que fuese contradictorio con esta natural adherencia el principio de unión entre todos los matices que habíamos anunciado y sostenido. Se había dado participación y no pequeña, al partido moderado en todos los destinos y cargos públicos; mas quisimos que quedase el gobierno en manos del partido del progreso exclusivamente»4!.

Con el mismo objetivo, el gobierno de López, siendo aún provisional, había nombrado a Olózaga ayo-instructor de Isabel II en los primeros días de agosto ${ }^{42}$. Conocida la adscripción de la camarilla palaciega que rodeaba a la futura reina, era de extrema necesidad para los progresistas colocar en el Palacio Real a un miembro de su partido que, revestido de la mayor dignidad, probada su solvencia y con un espíritu inequívocamente constitucional, fuera capaz de contrarrestar la contaminación política que asfixiaba a la princesa y, de paso, estrechara la vigilancia, como un atento centinela, sobre intrigas y manejos ${ }^{43}$. Pero a los progresistas se les fue complicando la situación cada vez más y ahora no iba

${ }^{41}$ López, J. Ma ${ }^{2}$ : Exposición razonada ..., pp. 129-130

42 La documentación relativa a este nombramiento, en Archivo General de Palacio (Madrid), Personal, Caja 756, exp. 43.

${ }_{43}$ Más tarde, el mismo López hizo pública aquella intención cuando en el Congreso aseguró: «tomamos algunas medidas, y entre ellas la de nombrar al Sr. Olózaga para que pudiera neutralizar el efecto y las influencias de los anteriores nombramientos, y no se le destinó, como ha significado un Sr. Diputado, para que formase camarilla, sino para que impidiera que otros la formaran». D. S., 9-XII-1843, p. 488. 
a ser tan fácil convencer a Olózaga para que el poder siguiera teniendo el mismo color. La dificultad para la gobernabilidad la había detectado Joaquín María López que, por experiencia propia, aseguraba que uen el alto gobierno no caben amalgamas en proporciones desiguales ni iguales, sin que sean una burla más bien que una fusión en el primer caso, o se produzca en el segundo un fatal entorpecimiento y una funesta parálisis». Consciente de que tal problema tenía, en aquella coyuntura, difícil solución, Olózaga —añadía López- «rehusaba tenazmente encargarse de la formación del ministerio y nos instaba con amistosa porfía a que continuasemos en el poder". Era conocida y admirada la experiencia política del agudo parlamentario, pero en esta ocasión, el aire espeso y viciado que se respiraba en los días previos a la formación de su gabinete, tiñó de pesimismo - como se desprende del relato de López- las esperanzas progresistas:

"Así preparadas las cosas, debo confesar que nos mostramos notablemente diligentes para lograr que el nuevo ministerio se organizase [...]. Nuestra ansiedad hasta conseguirlo era extrema. Notábamos en la atmósfera de ciertos lugares una de aquellas cosas que acaso no se explican, pero que se sienten. Nos parecía marchar con paso inseguro por un terreno minado que se estremecía a nuestras pisadas ${ }^{44}$.

Los moderados habían provocado la caída de López y ahora preparaban una jugada calculada para hacerse definitivamente con el poder. Mientras el ministerio saliente abogaba por la continuidad del progresismo en el gobierno, los moderados seguían tentando a Olózaga. Invocando aquellos la posición política del presidente del Congreso y apelando estos a las intenciones conciliadoras que venía exhibiendo desde la coalición antiesparterista, Olózaga, ampliamente reclamado, no podía insistir más en su negativa sin que pareciera una dejación irresponsable. Así lo entendió la prensa moderada que, dos días después del nombramiento de Olozaga, expresó justamente aquella idea:

«La crisis ha tenido la solución que esperábamos; pues aunque muchos creían que [Olozaga] resistiría por la centésima vez encargarse de la dirección del Estado, siempre pensamos que ya había llegado la hora para el Sr. Olózaga, si no quería incurrir en gran descrédito para con amigos, y para con adversarios. El hombre que solemnemente [...] invocó el nombre de Dios a favor de la Reina y del país [...] no podía menos de prestar su ayuda, cuando vencido el enemigo, la mano de Dios había sacado triunfante de la peligrosa lucha a su Reina y a su patria»'is.

Precisamente el halago a su responsabilidad fue el argumento que utilizaron los moderados para aconsejar a Olózaga, como única fórmula posible de

\footnotetext{
${ }^{44}$ Las sucesivas citas del testimonio de J. M². López: en Exposición razonada ..., p. 130.

45 El Heraldo, 22-XI-1843.
} 
garantizar la gobernabilidad, la formación de un gabinete mixto con cabida pata progresistas templados y moderados prudentes. Disfrazada de buenas intenciones, la verdadera aspiración de los moderados buscaba colarse en el gobierno por la puerta falsa $y$, al mismo tiempo, seguir erosionando la unidad progresista que reproduciría los enfrentamientos con motivo de la actitud de Olózaga. Si como era de esperar, el gabinete no funcionaba, habrían conseguido además, eliminar del mapa político al prestigioso dirigente progresista $\mathrm{y}$, como colofón, apartarlo de la reina, sobre la que venía ejerciendo una peligrosa influencia desde que dirigía su educación en calidad de ayo instructor.

Recién investido caballero de la Orden del Toisón de Oro, valorado su talento político por todo el arco parlamentario y reconocido su prestigio dentro y fuera de España, el temido orador y apasionado revolucionario que se había convertido en un circunspecto hombre de gobierno, aceptó al fin la oferta ${ }^{46}$. Según Joaquín María López, Olózaga no tuvo más remedio, aunque, «según todas las señales", asumió el compromiso "con notable repugnancia de parte suya ${ }^{47}$. El diputado de atinado discurso pudo consolarse creyendo que un gobierno dirigido por él y formado por hombres de conducta irreprochable y tendencia, aunque progresista, desapasionada, podría recomponer la situación. Después de todo, no era el progresismo como filiación lo que asustaba a los moderados, sino la estrategia inflexible y apresurada por la que se decantaban algunos de sus miembros más extremistas para desarrollar en profundidad y sin contemplaciones el programa liberal. La imagen de Olozaga, coincidente en el pasado con la de un ardoroso radical, se había ido suavizando hasta dibujar la fisonomía de un hombre siempre ligado al coraje parlamentario y a la palabra mordaz, pero de vocación constructiva y pensamiento práctico. Confrando en el amplio respaldo que acompañaba a su personalidad pública, Olózaga tomó posesión de la Presidencia del Consejo de Ministros y del Ministerio de Estado el 20 de noviembre de 1843 .

${ }^{46}$ En la época, fue nototia la celebridad de Olózaga en el extranjero. Durante su primer exilio tuvo la oportunidad de entablar numerosas relaciones, pero, sobre todo, en su etapa de embajador conquistó la amistad de personalidades influyentes y hombres de sobrada probidad. Como hizo constar Gumersindo de Azcárate, la farna de Olózaga "creció no poco [...] en las Cortes europeas, pudiendo bien decirse que durante el reinado de Isabel II era el único español cuyo nombre traspasaba los Pirineos y con cuya amistad se honraban personajes nocables de todos los países cultos». Véase AzCÁRATE, G. de: "Olózaga. Origen, ideas y vicisitudes del partido progresista», en La España del siglo XIX. Colecrión de conferencias bistóricas, Madrid, 1886, Tomo II, p. 11. En cuanto al nombramiento de caballero de la Orden del Toisón y la entrega del collar discincivo el 16 de septiembre de 1843, el expediente se conserva en el Archivo General de Palacio (Madrid), Sección Histórica, Caja 2-1, exp. 69.

${ }^{47}$ LÓPEZ, J. M.: Exposición razonada ..., p. 131. 


\section{LOS NUEVE DÍAS DEL GOBIERNO OLÓZAGA Y EL BLOQUEO DE LAS EXPECTATI- VAS PROGRESISTAS.}

La formación del nuevo gobierno fue más difícil de lo que cabía suponer. Olózaga, consciente de la encrucijada política que se había planteado, tenía que extremar su habilidad. No podía frustrar las esperanzas progresistas, pero tampoco debía irritar el humor de los moderados. Desde la prensa progresista se le pedía coherencia, utilizando el recurso de espolear su orgullo para inclinar las decisiones de Olózaga en favor de su partido:

«no debemos perder nunca de vista que el actual presidente del gabinete es una de aquellas personas más dificiles de calificar en política. Tal vez al aceptat el honroso encargo de colocarse al frente de la administración pública, se habrá decidido a arrostrar con constancia y sin volver la cara atrás, todas las consecuencias de una situación combatida por muchos de los mismos que la han creadon 48 .

Al mismo tiempo, los periódicos moderados cerraban filas en torno a Olózaga y se mostraban seguros de que tan distinguida personalidad podría satisfacer, a través del consenso y la reconciliación, el deseo unánime de alcanzar la paz, el orden y la estabilidad. Prolongando la táctica del halago, El Heraldo destacaba las "relevantes prendas" del jefe de gobierno y auguraba un feliz porvenir al país, dando por hecho que Olózaga - dotado del más fino olfato político- sabría dar la solución necesaria:

«más de una vez la nación ha admirado en el Sr. Olózaga sus grandes dotes parlamentarias, el talento que ha poseído casi siempre de prever los acontecimientos, que no parece sino que ha tenido a veces ante sus ojos el libro del porvenir; todo esto reunido hace que todos, y nosotros los primeros, abtamos el pecho a la esperanza, esperando confiadamente en que el sistema de gobierno del Sr. Olózaga va a remediar los males que afligen a nuestra patria. [...] Todas las clases del Estado desean ORDEN en esta monarquía $[$...]. No más revolución; basta ya [...] porque en pocas horas pueden trastornarse los principios vitales en que descansan la seguridad individual, la de la propiedad, y las demás garantías [...]. El Sr. Olózaga, como tan entendido, habrá conocido las necesidades de la época [...]; si quiere, y no lo dudamos, cubrirse de un inmarcesible lauro, y semejarse a los verdaderos hombres de Estado de todas las épocas, debe ser el intérprete de la opinión de su tiempo [....]; el acierto en la elección de los colegas del Sr. Olózaga $[\ldots]$ no lo dudamos ciertamente, porque S. S. tiene muchos amigos, mucha experiencia, y se ha visto en ocasión de apreciar debidamente hasta por quilates, el mérito de las personas que pueden jugar en estas combinaciones»49.

19 Eco del Comercio, 26-XI-1843.

49 El Heraldo, 22-XI-1843. 
La prensa moderada confiaba en el éxito de las gestiones que sus partidarios estaban llevando a cabo para ser incluidos en el gobierno y hasta el diario esparterista $E l$ Espectador confesaba su disposición a prescindir de "todo espíritu de partido" y «afecciones particulares» con tal de que una "cooperación franca y honrada» desterrara de España el «estado de postración a que la han reducido la ambición mezquina de los partidos» $\$ 0$.

Pero, más inteligente que vanidoso, el nuevo jefe del gobierno burló las expectativas moderadas y no contó con ninguno de sus representantes para componer su gabinete. Doménech en Gobernación, Claudio Antón de Luzuriaga en Gracia y Justicia, Francisco Serrano en Guerra, Manuel Cantero en Hacienda y Joaquín Frías en Marina, fueron los nuevos ministros progresistas. Disimulando su decepción, la prensa moderada saludó la fórmula elegida finalmente por Olózaga para formar gobierno, pero anunció que sería inflexible con sus actos:

«El Sr. Olózaga ha creído necesario para llevar adelante su sistema, que hubiese homogeneidad de opiniones políticas en las personas que compusiesen el ministerio, y si S. S. ha creído indispensable esa condición para que el gabinete tuviese Ia fuerza necesaria, si de esa escrupulosa uniformidad ha de resultar unidad de miras y de acción, y de ella la fuerza en el poder; nosotros, que algo teníamos tal vez que reclamar, nos sometemos voluntariamente, con tal de que se cumplan los deseos y se satisfagan las necesidades del país. [...] Para nosotros siempre han sido subalternas las cuestiones de personas; en lo que no cederemos un ápice será en las cuestiones de principiosns1.

El Eco del Comercio se felicitó por la elección de los ministros progresistas; aunque, más cauto, prevenido por los últimos sucesos que acompañaron la caída de López y manteniendo cierta desconfianza, prometió su apoyo al gobierno sólo «si la Constitución de 1837 llega a ser una verdad»\$2. La opinión de El Espectador fue más comprensiva y para contrarrestar las distintas quejas sobre la resolución adoptada por Olózaga, se apresuró a culpar a los moderados del avance progresista, sentenciando finalmente su discurso con un alarmante epitafio:

«El señor Olózaga $[\ldots .$.$] se ha debido convencer que el exclusivismo del parti-$ do moderado, sus tendencias reaccionarias, hacen la unión tan deseada de todo punto imposible. El partido progresista [...] se ha puesto en guardia [...]. iQuiera el cielo que don Carlos no sea quien se aproveche de nuestras miserias y discordias!»53.

\footnotetext{
so El Espectador, 22-XI-1843.

s1 El Heraldo, 26-XI-1843.

32 Eco del Comercio, 26-XI-1843.

33 El Espectador, 24-XI-1843.
} 
Planeando todavía la sombra del carlismo sobre el régimen constitucional, no fue este periódico el único en advertir del peligro. Otros, como El Corresponsal, pedían unidad a los dirigentes políticos para que este «enemigo común que trabaja con actividad y sin descanso" no se aprovechara de «nuestras interiores disidencias $\$$ \$. La llamada no era inoportuna porque en aquel tío revuelto los reaccionarios volvían a pescar con éxito garantizado. Alguno de sus portavoces, como El Católico no dudó en lamentar la llegada de Olózaga al poder que «traía a la memoria la ruina de millares de templos y de conventosnss.

Consciente de las distintas presiones, Olózaga se atrevió a desafiar las intenciones de los moderados. Según Rico y Amat, pretendía «unir y organizar al partido progresista, devolviéndole su fuerza y homogeneidad de ideas, con que se alzó poderoso en septiembre de $1840 \$^{36}$. Pero ni siquiera contaba con el respaldo absoluto y bien compactado de sus propios correligionarios. La composición del nuevo ministerio fue muy complicada. Olózaga tardó tres días en completar el gabinete después de recibir sucesivas negativas por parte de algunos hombres de su confianza. Aunque finalmente aceptó, uno de los más reticentes fue el general Serrano, reconocido militar cuyo pasado reciente había quedado unido al levantamiento contra Espartero. El Eco del Comercio valoró en el general su capacidad para "captarse la benevolencia de todos los partidos» y lo señalaba como "piedra angular entre progresistas y moderados" ${ }^{57}$. Quizás por eso mismo, Serrano se resistió a entrar en el gobierno. No le convenía al militar arriesgar su prometedora carrera tomando parte en un ministerio sobre el que se cernían malos presagios. Además, Serrano tampoco podía traicionar la confianza de los moderados que le consideraban, junto a Narváez, un valor en alza. Durante la formación del gabinete, la prensa se hizo eco de la actitud refractaria del general y se habló, incluso, de condiciones que Serrano habría impuesto a Olózaga antes de claudicar. Días después, el propio militar confirmó en el Congreso que habían sido tres las peticiones exigidas. Serrano, necesitaba en primer lugar el visto bueno del gobierno precedente, quería en el nuevo

${ }^{34}$ El Corresponsal, 23-XI-1843.

"El Catolico, 27-XI-1843. La alusión recordaba la vinculación de Olózaga con la exclaustración de religiosos y con la demolición de sus edificios mientras ocupó el gobierno civil de Madrid. En el ejercicio de su autoridad se produjo la supresión total de conventos que, según Josefina Bello, fue acelerada «a instancias" de Olózaga con la intención de equitar así todo pretexto a los revolucionarios», cuya furia anticlerical estaba poniendo en apuros al gobierno progresista. Además, el gobernador civil presidió a partir de febrero de 1836 la Junca de Enajenación; organismo encargado de «diar aplicación y destino útil a los edificios que han resultado vacantes». La Junta resolvió derribar algunos conventos para mejorar el trazado urbano de Madrid, construir plazas y abrir nuevas calles. Peto al mismo tiempo, se trataba de una gran operación especulativa basada en la *obtención de beneficios sobre los materiales procedentes de la demolición y en la venta de solares resultantes». Ver BeLLO, J.: Frailes, intendentes y poltticos. Los bienes nacionales, 1835-1850, Taurus, Madrid, 1997, pp. 120,250 y 255 , respectivamente.

56 Rico y AMAT, J.: Historia Politica ..., Vol. III, p. 411.

${ }^{57}$ Eco del Comercio, 26-XI-1843. 
gabinete a algún compañero del anterior y solicitaba un ministerio para González Bravo ${ }^{58}$. Olózaga cumplió una parte del trato colocando a Joaquín Frías en el ministerio de Marina, pero se negó a dar entrada en el gobierno al peligroso González Bravo, bien conocido en la escena política por dirigir la facción de la Joven España y no menos famoso como editor de El Guirigay, corrosivo periódico en el que González Bravo bajo el seudónimo de Ibrahim Clarete vociferó sus agresivas cencerradas ${ }^{59}$. La firmeza de Olbzaga fue aplaudida por el Eco del Comercio que celebró la designación de Jacinto Félix Doménech para ocupar el ministerio de la Gobernación «en lugar de otra persona cuyo nombre ha corrido de boca en boca con escándalo de cuantos le oían"60.

Pero lo que unos aprobaban, a los otros contrariaba, y el enredo político no llevaba camino de deshacerse. Si la prensa progresista alabó la exclusión de González Bravo, los periódicos de signo opuesto criticaron con dureza el nombramiento de Doménech. El que había sido recientemente alcalde constitucional de Madrid se convirtió en la víctima de todos los reproches moderados. Estos consideraron su investidura un agravio parlamentario puesto que, al interrumpirse en Cataluña las elecciones de septiembre con motivo de la sublevación centralista, Doménech —apuntaba $E l$ Heraldo - «no sabemos corresponda a ninguno de los dos cuerpos colegisladores $[y]$ aun dado que hubiera merecido la confianza de alguna provincia, no se sabe a qué fracción hubiera pertenecidom. No es lo mismo -añadía el periódico- un "ministro diputado" que un «diputado ministro» 61 .

Con mucha crispación y voces que ya auguraban la interinidad del ministerio, Olózaga empezó su tarea de gobierno por lo más difícil: los ayuntamientos y la Milicia. Pendientes de solución, aquellos problemas heredados del ministerio López merecían suma delicadeza en su tratamiento, pero no cabía eludir la responsabilidad de abordarlos. La víspera del nombramiento de Olózaga, el gobierno saliente había mandado proceder a la elección de ayuntamientos por la ley vigente de 1823 , pero el Senado en su sesión plenaria del día 20 de noviembre y el Congreso en su reunión del día 21, discutieron sendas proposiciones que planteaban la suspensión de la orden emitida por Fermín Caballero. Para responder a la inquietud que crecía en torno al asunto, Olózaga avanzó su intención de preparar una nueva ley de ayuntamientos que, discutida en el foro parlamentario y aprobada por mayoría, permitiera reorganizar la administración local con garantías. La medida logró detener el proceso de reelección mu-

58 D. S., 2-XII-1843, p. 338.

${ }^{59}$ Así se denominaba la sección en la que González Bravo vertía improperios, insultos y afilados dislates desde El Guirigay. El periódico tuvo una existencia corta - -de enero a julio de 1839-, pero dejó una huella imborrable. Como recordaba $\mathrm{M}^{\mathrm{a}} \mathrm{C}_{\mathrm{i}}$ Seoane, en su edesaforada demagogia» el pendenciero redactor llegó a referirse a la regente Maria Cristina con los términos de «ilustre prostituta». Véase SEOANE, M.C.: Historia del periadismo en España. El siglo XIX, Alianza, Madrid, 1989, p. 181.

to Eco del Comercio, 26-XI-1843.

${ }^{61}$ El Heraldo, 26-XI-1843. 
nicipal en espera de la prometida ley y la prensa de todas las tendencias resaltó lo conveniente de este anuncio con una satisfacción generalizada.

Sin embargo, no produjo el mismo efecto la cuestión de la Milicia Nacional. El decreto sobre su reorganización con el que se despidió Caballero del ministerio, fue más contestado que la renovación de ayuntamientos. Al fin y al cabo, las últimas turbulencias habían permitido el acceso de los moderados al gobierno local que, dada su participación en la coalición antiesparterista, acabaron ingresando en los ayuntamientos nombrados por las juntas revolucionarias de julio62. Por esta razón fundamental, los moderados quisieron paralizar una reelección que no convenía a sus intereses y sólo porque confiaban en sus posibilidades para alcanzar el poder en breve, contuvieron su vigor político frente al compromiso de Olózaga para redactar una nueva ley. Peto si el estado de los ayuntamientos no les preocupaba por el momento, la reorganización de la Milicia alteraba sus más primarios instintos políticos. $\mathrm{La}$ institución había sido tradicionalmente el brazo ejecutor de las proclamas revolucionarias y su función como vanguardia del liberalismo había servido para encauzar la construcción del Estado burgués. Mientras la Milicia se nutrió de propietarios, no hubo motivos de alarma, pero ahora se estaban incorporando de forma paulatina soldados procedentes de clases inferiores, de tal manera que el alistamiento ciudadano empezó a plantear reivindicaciones propias que venían a coincidir con demandas populares. Armada y con extraordinario poder para seducir a la multitud, desde los acontecimientos que lograron desplazar a Espartero del poder el rumbo de la Milicia puso en guardia a todos los defensores del orden y alertó particularmente a los moderados que, además de presumir esa condición, venían demostrando su preferencia por el ejército, y no la Milicia, como único cuerpo armado para la seguridad del Estado ${ }^{63}$.

Así las cosas, los moderados intentaron bloquear el proceso de reorganización mandado por Caballero y se volcaron en una feroz campaña periodística para deteriorar la imagen de la Milicia. Desde el mismo día en que Olozaga consiguió formar el gobierno y sin haberse hecho pública aún la lista de ministros, El Heraldo ya se refería a un saneamiento del ejército urbano como asunto de vital importancia, toda vez que se conocía la degeneración progresiva de la organización:

«La milicia nacional es uno de los objetos en que habrá de fijarse al momento la atención del gobierno, cualquiera que sea la índole y las circunstancias con que se presente al país el nuevo gabinete. Desarmada en algunas partes, delincuente y perturbadora del orden en otras, leal y decidida en favor del trono y la Constitución en muchas, y resintiéndose de una mala organización en todas, preciso es

62 La explicación del problema de los ayuntamientos en diciembre de 1843, en C. de Castro, La revolución liberal ..., pp. 165-166.

63 Véase al respecto, Pérez Garzón, J. S.: "Ejército nacional y Milicia nacional», Zona Abierta, $\mathrm{n}^{\circ} 31,1984$, pp. $23-42$.

Hispenia, LX/2, núm. 205 (2000) 623-672 
echar sobre ella una profundísima mirada [...]. Al pensar que no ha habido en España un solo desorden en que nombre tan respetable no intervenga [...] y que en España, tal como se halla, es sólo un instrumento para triunfar contra los poderes públicos y para crear juntas y revolver desde sus cimientos el Estado, confesamos que la institución, tal como se encuentra, no la juzgamos saludable» ${ }^{64}$.

Ante las protestas y los requerimientos, Olózaga tuvo que invalidar las disposiciones del gobierno anterior y prometer, también en este caso, una nueva legislación sobre la Milicia. La prensa moderada, partidaria de suspender su actividad hasta que fuera promulgada aquella ley, juzgó sensato el ofrecimiento. Pero los periódicos progresistas no veían inconveniente en mantener armada a la Milicia mientras se discutiera el proyecto para su reorganización. En este sentido, el Eco del Comercio consideró la postura de Olózaga un tremendo atropello y acusó al ministro de la Gobernación de atentar contra los principios del progresismo:

«Ya habrá cesado la alarma de los diarios moderados, que miraban con ojeriza al gabinete Olózaga, esencialmente progresista. Ya habrá cesado el encono de El Heraldo y La Posdata contra el señor Doménech, alcalde revolucionario, en su concepto, cambiado como por ensalmo en ministro conservador. Ya no hay que abrigar el temor de que haya milicia que contrarreste los planes reaccionarios: la situación ha cambiado en una noche. [...] Mucho celebramos no haber tenido que esperar algún tiempo para conocer a los hombres [...]. iQuién lo dijera! Hoy vemos al alcalde constitucional de Madrid que invocaba el nombre de la milicia y su pronta organización como la salvaguardia de nuestras libertades, oponerse a aquella medida salvadora, y decretar como ministro lo que había resistido como concejal. ¿Qué conducta es esta? ¿Cómo se califica?»65.

La irritación que produjo el asunto alcanzó la máxima tensión el día 26 de noviembre. El Ayuntamiento de Madrid, desoyendo las recomendaciones del ministro Doménech, inició el rearme de la Milicia acogiéndose al último decreto de Fermín Caballero. El acto de insubordinación fue tajantemente reprendido por el gobierno, que mandó interrumpir el proceso de forma inmediata. La respuesta fue una espontánea algarada que el nuevo ministerio se vio obligado a reprimir con dureza y severidad. La crispación de los progresistas —en su percepción, cada vez más humillados- iba aumentando, aunque bien es cierto que los más pacientes, como Madoz, siguieron mostrando en el Congreso su adhesión al gobierno no sólo en materia de milicia, sino también en lo saludable de impedir los excesos revolucionarios. El destacado progresista, representando a un buen número de diputados aliados, aclaró desde su escaño que defendían "la causa de la libertad», pero «hermanada con el orden público" y que

${ }^{64}$ El Heraldo, 24-XI-1843.

6s Eso del Comercio, 27-XI-1843. 
«querían milicia en Madrid», pero "como debe de estar»66. Fueron los más avanzados, que ya habían dado muestras de la insumisión al progresismo o incluso se habían desligado de su discurso, quienes acorralaron a Olózaga pidiendo explicaciones por lo sucedido en las calles de Madrid. En el inicio de la sesión del día 27, Wenceslao Ayguals de Izco fue el primero en interpelar al presidente del consejo y después tomó el relevo el conde de las Navas. Ambos parlamentarios eran conocidos por su identificación con el movimiento democráticofederal que había estrenado su independencia oficial del progresismo en 1842 cuando Ayguals publicó en La Guindilla, periódico republicano de su propia factura, el nacimiento del partido ${ }^{67}$. La inspiración republicana de Wencesiao Ayguals se había desarrollado con cierta timidez, pero Luis Pizarro, conde de las Navas, venía demostrando esa incipiente inquietud casi desde sus orígenes políticos ${ }^{68}$. Ayguals, portando el estandarte de los «derechos del pueblo soberano», exigió en el Congreso que se tomaran medidas contra la fuerza pública que había castigado el alboroto. En tono demagógico, el diputado republicano acabó por añadir que si se trataba de imponer las decisiones políticas, no dejaría de luchar por la libertad del país «aunque viese la cuchilla del verdugo levantada sobre mi cabeza»"69. Olózaga quiso atajar la escalada de críticas y respondió con su habitual contundencia:

«El gobierno de S. M. puede decir que ha tomado medidas muy severas [...] y si el Sr. Ayguals [...] no terne la cuchilia de un verdugo, los Ministros de S. M. no temen todas las cuchillas y todos los puñales de todos los verdugos y asesinos de Madridn 70 .

Después de un prólogo tan efectista, el discurso del jefe del gobierno se detuvo con más recato en la exposición de los hechos y, sobre todo, en la explicación del ánimo que llevó a frenar el rearme de la Milicia. Según sus palabras, este no era otro que procurar "una transición prudente" hacia lo que "la ley y la situación actual requieren» ${ }^{71}$. Los oponentes políticos no se dieron por satisfechos con los argumentos de Olbzaga. El debate se prolongó con la incisiva

66 D. S., $27-\mathrm{XI}-1843$, p. 288.

${ }^{67}$ Además de explicar la fundación de la corriente tepublicana, Jordi Maluquer apuntó algunas notas biográficas sobre Ayguals de Izco que permiten situar al personaje entre los miembros más descacados de la burguesía mercantil. Véase El socialismo en España. 1833-1868, Crítica, Barcelona, 1977, pp. 282-284.

68 Además de en la obra de Maluquer, puede verse la difícil posición del republicanismo durance los años de la regencia de Espartero en el artículo de Demetrio Castro. El autor recoge la evolución política de Ayguals y señala la importancia del conde de las Navas como «figura relevante y patriarcal del primer republicanismon. Ver «Orígenes y primeras etapas ...*, pp. 45-48.

${ }^{69}$ D. S., $27-\mathrm{XI}-1843$, p. 279.

70 lbid., p. 279.

"lbid., p. 286. 
intervención de Ovejero en favor de la postura adoptada por el ayuntamiento de Madrid y con el arrebato populista de González Bravo que se proclamó, sin ningún rubor, el más amante de la Milicia Nacional. Mientras la discusión giraba en torno a la necesidad de una ley nueva para la institución, el conde de las Navas volvió a insistir en que fuera aclarado lo tocante a los disturbios públicos ocurridos el día 26. Esta vez la respuesta de Olózaga fue corroborada y ampliada por el jefe político de la provincia, el moderado Manuel Mazarredo, colaborador fiel de Narváez y partícipe de sus intrigas que posteriormente acabaría siendo recompensado con el Ministerio de la Guerra. Al general Mazartedo correspondía dar cuenta de todo lo ocurrido en el ayuntamiento cuando, en su presencia y después de transmitir la orden del gobierno sobre el desarme de la Milicia, se inició su discusión plenaria. Y como jefe político también le tocaba asumir la responsabilidad de los actos protagonizados por la fuerza policial. Su declaración parlamentaria incluyó todos los detalles sobre la reunión municipal, pero fue más concisa en cuanto a la alteración popular; asunto que en opinión del agente del gobierno, se había distorsionado intencionadamente con la finalidad de lanzar "bombas incendiarias" que impidieran «los intentos que todos tenemos de reconciliación ${ }^{72}$. Resultaba obvio que los republicanos albergaban un interés concreto en desprestigiar a Olózaga como líder principal del progresismo en beneficio de su propio partido y, dadas las circunstancias, nada podía deteriorar más su atractivo que poner en evidencia el verdadero rostro político de los apoyos con los que contaba. Por lo tanto, la intercesión de Mazarredo, que como un resorte salió al paso de la provocativa insistencia del conde de las Navas, vino a rubricar el objetivo perseguido.

Subidas de tono, las recriminaciones de los republicanos y de algunos progresistas afeaban cada día más la cara del nuevo ministerio. Para compensar a los de su bando y acallar a los más inconformistas, Olózaga tuvo que hacer algunas concesiones que, como era de esperar, teavivaron el malestar de los moderados. La más osada fue la publicación de un real decreto por el que se revalidaban todos los empleos, gracias, honores y condecoraciones concedidos por Espartero hasta el día 30 de julio de 1843, fecha en la que abandonó el país. Zaherido el orgullo de los moderados, todos los diarios de su filiación interpretaron la orden como un intento de neutralizar la presión creciente que ejercía sobre el gobierno su propia parentela política. Además, reponer aquellas dignidades venía a significar la legitimación misma de la regencia hasta el último día en el que Espartero permaneció en suelo español. Lo que los moderados consideraton en principio una contradicción, fue tachado, después del primer análisis, de tremenda descortesía hacia toda la coalición antiesparterista que se había unido - -así lo creían- en contra de un traidor al que ahora se le reconocían legítimos derechos. Sin embargo, la ocurrencia de Olbzaga no era un simple remedio para anular las críticas. Todos los periódicos publicaron el decre-

72 Ibid., p. 289. 
to, pero sólo El Heraldo reparó en el preámbulo para sacar conclusiones sobre el verdadero objetivo que había impulsado al gobierno a tomar la decisión:

\footnotetext{
«Hacer extensiva la reconciliación a ciertas personas que podrán ser muy útiles; quitar cualquiera motivo de queja y resentimiento a buenos patriotas, que pueden sustituir en caso necesario a otras personas de su misma profesión que por desgracia pertenecen ahora todas a una misma comunión política, circunstancia que infunde alarma y sospechas, ha sido sin duda lo que el gobierno se ha propuesto conseguirn 73 .
}

Efectivamente, ya desde el gobierno provisional de López era conocida la peligrosa presencia de Narváez en la capitanía general de Madrid. Los progresistas sabían de sus manejos para devolver el poder a los moderados y, aunque supo disimularlos mientras fue necesario, lo cierto es que el general estaba diseñando un ejército a su medida. Cercenada la posibilidad de reorganizar la Milicia, engordada la fuerza parlamentaria de los moderados, divididos los progresistas y acosado el gobierno, había que salvar, al menos, el ejército. Si las fuerzas militares caían definitivamente en manos de los moderados, la continuación del progresismo en el poder sólo dependería de sus caprichos políticos y, por lo tanto, su supervivencia era cuestión de tiempo. Así pues, el gobierno planteó en realidad un duelo contra Narváez y para no defraudar a su público, el general lo aceptó. Según los periódicos, nada más conocerse el decreto, Narváez manifestó su obligación de dimitir. Pero la jugada tenía una segunda parte, y consistía en arrastrar con él al general Serrano. Al Ministro de la Guerra tampoco debió agradarle la confirmación en sus puestos de aquellos a los que la coalición había combatido y por si acaso él mismo no lo hubiera pensado, $E l$ Heraldo se encargó de recordárselo en cuanto tuvo noticia de la resolución ministerial:

«Si el gobierno del ex-regente fue legítimo hasta el día 30 de julio iqué será el general SERRANO que destituyó a D. BALDOMERO ESPARTERO de esa Regencia legítima y que anuló cuanto de aquel gobierno proviniese?»?4.

El Castellano todavía fue más lejos, llamando la atención sobre el «papel ridículo» al que Serrano se veía sometido por el espíritu del decreto, lo que incluso podía acarrear la mofa del ejército y comprometer la admiración de sus mejores amigos ${ }^{75}$. Con el camino desbrozado por la prensa moderada, el llamado general bonito atendió las consideraciones de Narváez y presentó su dimisión. Fue $E l$ Espectador el diario que dio mayor cobertura a los rumores y el día 29 de

\footnotetext{
73 El Heraldo, 28-XI-1843.

${ }^{74}$ El Heraldo, 28-XI-1843.

7s El Castellano, 29-XI-1843.
} 
noviembre publicó una pequeña crónica incluyendo la descripción completa de los hechos:

\begin{abstract}
"Asegúrase que no estando conforme el general Narváez con la nueva situación [...] lo dio así a entender al señor Serrano epistolarmente, manifestándole al propio tiempo que se veía en la necesidad de dimitir su destino de capitán general. Este incidente concurrió con un motivo de disgusto que se dice tuvo en el mismo día el señor Serrano con los demás ministros, y como al presentarse al señor Olózaga con la carta del señor Narváez, encontrara al presidente del consejo de ministros muy frío y dispuesto a recomendar a S. M., no sólo la dimisión del capitán general, sino también la suya insistiendo en ella, de aquí la vacante que se supone en el departamento de la guerra y la que se dice en la capitanía general de este distritom 76 .
\end{abstract}

Como si el gobierno no tuviera ya bastantes frentes abiertos, la delicada situación todavía se resintió más cuando el Congreso procedió a la elección para nombrar un nuevo presidente en sustitución del ascendido Olózaga. Los progresistas propusieron la candidatura de Joaquín María López porque en vista de las circunstancias, ni siquiera se atrevieton - como indicaba Valera- a presentar a Cortina, lugarteniente de los puros ${ }^{77}$. Aún así, nada pudo evitar que finalmente triunfara la opción de los moderados, y el resultado de la votación favoreció a Pedro José Pidal, uno de sus más genuinos representantes. La elección parlamentaria puso de relieve el desequilibrio de las fuerzas políticas y demostró que el bando modetado tenía suficiente respaldo como para derrotat al adversario en sucesivas batallas. El Heraldo habló de una «izquierda» compuesta por viejos progresistas y otros allegados, más partidarios «de la libertad que del orden»; de una "derecha» integrada por moderados «de gran cuenta y valía»; y de un "centro» —en alusión a la Joven España de González Bravoformado por «cuarenta jóvenes» procedentes de los dos partidos mayoritarios que aspiraban a «regirse por sus propias inspiraciones» basadas en una política "peculiar». En cualquier caso, la unión del "centro" y la "derecha" había zanjado «la cuestión de mayoría y minoría», asunto que "era necesario ventilar»78. El Eco del Comercio, más lacónico, se limitó a reseñar que la elección de presidente había resuelto "el problema de la mayoría" y siendo esta moderada, "no creemos muy lejana --se sinceraba el periódico- una nueva crisis». En su comentario sobre la elección de Pidal, el Eco vaticinó, incluso, que «en caso de oposición marcada", Olózaga tendría que buscar refuerzos, aunque fuera "prematuro» anunciarlo, "explorando de nuevo la voluntad de la nación»"s. Poco se equivocaba el periódico progresista. El infortunado gabinete no tenía

${ }^{76}$ El Espectador, 29-XI-1843.

" LAFUENTE, M.: Historia General de España ..., Tomo XXII, p. 402.

78 El Heraldo, 28-XI-1843.

79 Eco del Comercio, 29-XI-1843. 
apoyo parlamentario y, además, estaba enfrentado internamente con su propia división desde que el general Serrano planteara su retirada del Ministerio de la Guerra. Los moderados decidieron no dar más cuerda al progresismo y plantear al gobierno de Olózaga un último reto: si el ministerio quería seguir en el poder, el presidente del consejo estaba obligado a disolver las Cortes y convocar elecciones.

Consciente de la situación, Olózaga no quiso, sin embargo, rendirse indignamente, ni tampoco afrontar la agonía a la que su gobierno parecía condenado. Decidió disolver las Cámaras en cuanto la hostilidad parlamentaria se manifestara, pero creyó que podría hacerlo por sorpresa y sin previo aviso. De esta maneta quedaría intacta la autoridad del progresismo, nadie se atrevería a insinuar que no contaba con el apoyo de la Corona y, además, abriría un paréntesis político apto para la reflexión y la reacción de su propio partido. Nada hacía sospechar que la maniobra fuera arriesgada y, desde luego, era la única salida que, si prosperaba, podía garantizar la prolongación de su mandato. A tal efecto, Olózaga se entrevistó con la reina en el Palacio Real y obtuvo la firma del decreto de disolución. Nunca pudo imaginar lo caro que pagaría aquel último desafío a sus enemigos políticos.

\section{LA ACUSACIÓN MODERADA Y EL DESPRESTIGIO DE OLÓZAGA: LA DERROTA DEL PROGRESISMO EN 1843.}

A pesar de la discreción con la que Olózaga actuó, sus oponentes políticos no tardaron en conocer la noticia. La camarilla, que alojada en el Palacio Real conducía la voluntad de Isabel $\mathrm{II}$, sospechó que la reunión del Presidente del Consejo con la reina no respondía a un despacho habitual. Pensaron que Olózaga se había dirigido al palacio buscando la rúbrica a la dimisión de Narváez, pero interrogada la cándida niña, supieron que lo que había firmado era el decreto de disolución de las Cortes. Con aquel instrumento legal, Olózaga no temía la oposición parlamentaria que, al menor síntoma de obstrucción, sería sorprendida con la suspensión de la legislatura. Además, de manera indirecta, el jefe del gobierno puso a sus detractores en un nuevo apuro porque ahora, una vez enterados de la intención, tendrían que determinar si convenía practicar una política agresiva con un final anunciado o era preferible enmudecer. Sin embargo, todavía quedaba una tercera posibilidad fuera del reglamento político y al margen de la normativa parlamentaria. Si la osadía de Olózaga podía ser considerada un atentado contra el Estado, cualquier método para contestarla era legítimo. En estos términos estimaron los moderados el incidente y, según Juan Valera, resolvieron adelantarse a sus efectos preparando contra Olózaga un zarpazo definitivo:

«Era un golpe de Estado que Olózaga quería dar contra ellos y el cual no se podía parar sino con otro. Era un duelo a muerte en el cual todas las armas eran

Haspania, LX/2, núm. 205 (2000) 623-672 
buenas con tal de que matasen. Olózaga tenía la suya, afilada ya, pero sin atreverse a esgrimirla. Importaba, pues, apoderarse en seguida de otra arma, fuese la que fuese, y asestar contra Olózaga un tiro certero y mortífero» 80 .

No por casualidad, fue El Heraldo el primero en confirmar los rumores que se extendían por todo Madrid sobre la inminente disolución de las Cámaras. En su edición del día 30 notificó la visita de Olózaga al Palacio Real, ocurrida en la noche del 28, y aclaró que el Presidente del Consejo tenía en su poder el documento para la interrupción de la legislatura. Pero acompañaba a la noticia la insólita acusación de que Olózaga había obtenido la sanción del decreto «arrancando violentamente y contra su voluntad» la firma de la reina. El artículo cơncluía comunicando que el Ministro de Marina, Joaquín Frías, había sido el encargado de expedir la exoneración de Olózaga de sus cargos de Presidente del Consejo de Ministros y Ministro de Estado ${ }^{81}$.

Apenas mediaron horas entre la conversación de Olózaga con la joven Isabel II y el inédito desenlace. La plana mayor de los desafectos al gobierno se dio cita en el Palacio Real y, alegando haber sido convocados por la reina para participarles el abominable abuso, levantaron acta de lo sucedido con la pluma de González Bravo, cuya presencia estaba justificada en calidad de notario mayor del reino y en función de su fulminante ascenso a Ministro de Estado. Entre otros - y además de los funcionarios reales, jefes de la guardia, mayordomos y camareras - en la declaración de la reina estuvieron presentes Onís, el duque de Rivas y el conde de Ezpeleta como presidente y vicepresidentes del Senado; Pidal, Andrés Alcón, Mazartedo y Javier de Quinto por desempeñar las mismas funciones en el Congreso; Ramón María de Lleopart, presidente del Supremo Tribunal de Justicia; Francisco Ferraz, presidente del de Guerra y Marina; el duque de Frías, presidente de la Junta Consultiva del Ministerio de Estado; el duque de Castroterrero, decano de la Diputación de la Grandeza de España y presidente de la Junta Consultiva de Guerra; José María Nocedal, decano de la Diputación de Madrid; Manuel Larrain, alcalde primero constitucional de Madrid; Francisco Serrano Domínguez, teniente general de los Ejércitos Nacionales y Ramón María Narváez, capitán general del Primer Distrito Militar. Es de suponer que los conocidos testigos, particularmente conspicuos los dos últimos, reconvinieron a la inexperta reina y, para anular definitivamente el prestigio de Olózaga, recomendaron una declaración inculpatoria de bajo estilo político y notable vulgaridad:

«En la noche del veinte y ocho del mes próximo pasado se me presentó Olózaga y me propuso firmar el decreto de disolución de las Cortes. Yo respondí que no quería firmarlo, teniendo para ello entre otras razones la de que estas Cortes

\footnotetext{
${ }^{80}$ LAFUeNite, M.: Historia General de España ..., Tomo XXII, p. 404.
}

${ }^{8}$ El Heraldo, 30-XI-1843. 
me habían declarado mayor de edad. Insistió Olózaga. Yo me resistí de nuevo a firmar el citado decreto. Me levanté dirigiéndome a la puerta que está a la izquierda de mi mesa de despacho; Olózaga se interpuso y echó el cerrojo a esta puerta. Me dirigí a la que está enfrente y también Olózaga se interpuso y echó el cerrojo a esta puerta. Me agarró del vestido y me obligó a sentarme. Me agarró la mano hasta obligarme a rubricar. En seguida Olózaga se fue y Yo me retiré a mi aposento. [...] Antes de marcharse, Olózaga me preguntó si le daba mi palabra de no decir a nadie lo ocurrido y Yo le respondí que no se lo prometia»82.

Al real manifiesto se le dio la máxima difusión y la insidia lanzada contra Olózaga, a pesar de su patética inverosimilitud, surtió el efecto deseado. Pero los moderados, todavía desconfiando de la acreditada astucia y el perspicaz talento de su enemigo político, se habían ocupado de elegir bien al actor secundario del drama. Ni Serrano, ni Narváez, ni ningún otro prohombre de la facción moderada podía comprometer su posición en un asunto sucio que, de fracasar - cosa improbable, pero posible dado el carácter político de Olózaga y la segura reacción de sus partidarios ante la afrenta- arrastraría en la caída su propia honorabilidad. Según la narración de Valera, aunque el autor no apuntó la explicación de la postura, "ningún personaje conservador de cierta importancia quería firmar esta acta». Así pues, se solicitaron los servicios de un afamado gallo de pelea que no podía ser otro que González Bravo. Este, añadía Valera, «se prestó a todo" y "el partido moderado se valió de él como instrumento ${ }^{83}$. El conocido agitador estuvo dispuesto, en consonancia con su atolondrado proceder político, a encabezar el enfrentamiento contra Olbzaga, mientras sus verdaderos verdugos quedaban, reservones y prevenidos, en un discreto segundo plano ${ }^{84}$.

82 El acta fue publicada en distintas fuentes impresas y en el Diario de Sesiones, pero la cita del texto, así como la anterior mención a los presentes, se basa en una de las copias originales conservada en el Archivo del Ministerio de AA. EE., Política (Circulares), leg. H-2726, exp. 346.

${ }^{83}$ LAFUENTE, M.: Historia General de España ..., Tomo XXII, p. 407.

${ }_{84}$ El perfil de González Bravo fue rrazado en numerosas ocasiones por la literatura polírica de la época, pero fue en la Historia General de España de Lafuente donde se dibujó uno de los retratos tnás completos sobre el personaje: «Capitaneaba un corto número de gente joven y ambiciosa que se daba o había aceptado el título de la joven España. Lo vago del lenguaje, lo pornposo de las formas y la frescura e impavidez de las expresiones vacías, tapaban la carencia de convicciones de esta juventud dotada; carencia de convicciones que no nacía de pecado o perversión de la voluntad, sino de irreflexión, de falta de estudio, de no haberse parado a meditar en nada. [...] En él había altas prendas que le hacian muy a propósito para medrar y engrandecerse en nuestro país. Prefiriendo nosotros mucho a Espronceda, todavía nos atrevemos a sostener que González Bravo fue político, como Esproceda poeta. A ambos les faltó colegio. También González Bravo pudo decir: Yo con erudicción icuanto sabría! [...] Y también pudo confesarnos que hacía política como el otro poemas, sin ton $n i$ son; $y$ añadir «allá van versos donde va mi gusto» trocando la palabra versos por la palabra discursos, programas o doctrinas. [...] González Bravo poseía cualidades mentales excelentes, algo desordenadas y viciosas en su misma lozanía, como plantas que crecen en matorral sin cultivo [...]. Apasionadísimo, entusiasta y lleno de sinceridad, aunque no de fijeza en sus entusiasmos y pasiones, 
Con la avanzadilla de González Bravo, la oposición había ganado la batalla, pero tenía que consolidar su victoria. Olózaga todavía contaba con los respetos de la mayoría de los progresistas y la prensa de su signo, que hasta ahora se había mostrado exigente, se volcó en arropar al que ya suponía su último baluarte. El Eco del Comercio no pudo ser más explícito en este sentido:

«Hemos hecho lealmente la oposición al señor Olózaga [...] pero en las actuales circunstancias, cuando nos vemos frente a frente con nuestros adversarios naturales, y estamos penetrados del origen de los hechos, y columbramos cuál será el desenlace de tan espantosa crisis, debemos colocarnos con igual lealtad de parte del caído, y exponer la verdad desnuda a los ojos del pais, que tiene derecho a que se le diga enteras 85 .

Especialmente significativa fue la postura que adoptó El Espectador que, viendo venir — como el $E c 0$ - la avalancha moderada, propuso «echar un velo a sucesos que pasaron y no interesa recordar» y lanzó una llamada «franca y amistosa a todos los liberales exhortándolos a la más estrecha unión si se ha de salvar la libertad y la independencia del pueblo español ${ }^{86}$. Los diarios progresistas incluyeron, además, la carta que les remitió el mismo Olózaga en la que, proclamando su inocencia, comunicaba haber procedido legalmente contra $E l$ Heraldo por la publicación del artículo del día 30:

«Señores redactores de EL ESPECTADOR. Muy señores míos: en EL HERALDO de hoy me veo atacado con tanta falsedad como violencia suponiéndome capaz de haber arrancado violentamente un decreto de S. M. Acabo de denunciar este articulo al JURADO como calumnioso; el juicio del país condenará a los torpes calumniadores, y la verdad triunfará de sus malas artes. Pero antes de ese día espero demostrar la falsedad del objeto de semejante imputación, que desmienten desde luego mi carácter, mi posición y los antecedentes de mi vida pública y privada. Para ello cuento con los medios de publicidad que gozamos los españoles, mal que les pese a los que prefieren los oscuros manejos y miserables intrigas inútiles para oscurecer el brillo de la razón y la justicia. Soy de vds. con la mayor consideración atento y seguro servidor $q$. b. ss. mm. - Salustiano de Olózaga - Madrid, 30 de noviembre de $1843 n^{87}$.

Como no podía ser menos, El Espectador también brindó todo su apoyo al ministro destituido y, a renglón seguido, añadió:

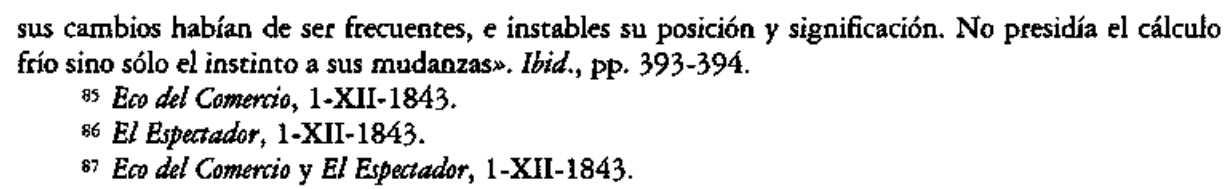


«A los medios de publicación apela el Sr. Olózaga: cuente nuestro antiguo y reciente amigo con todos los elementos de que EL ESPECTADOR puede disponer. Todos los liberales están en perenne agitación; ya no existen rencores ni denominaciones odiosas; todo se ha depuesto, porque todo se hacía necesario para salvar la libertad ${ }^{88}$.

Pero el presunto delito cometido por Olózaga alcanzó su verdadera dimensión política en el Congreso donde fue, durante varios días, materia de discusión parlamentaria. La sesión del 1 de diciembre se abrió con un tremendo alboroto y tuvo que ser interrumpida "porque entrando en el salón el Sr. Olózaga [...] se dieron fuertes aplausos en las tribunas" y no se pudo restablecer el orden $^{89}$. Cuando por fin se calmó el revuelo, el debate empezó por aclarar la situación parlamentaria del exonerado y los ministros Doménech, Cantero y Luzuriaga, que habían presentado su dimisión una vez enterados de la acusación. Si podían o no ocupar sus escaños y asistir como diputados a las discusiones, dependía de la aplicación del reglamento de las Cortes. La solución de esta formalidad fue, naturalmente, la primera ocasión para el enfrentamiento y ambos bandos pretendieron imponer su interpretación de la normativa parlamentaria. Al frente de los moderados, José de Posada proclamó que los exministros no tenían derecho a participar en la disputa por haber quedado sujetos a reelección después de cesar en sus cargos. Pero Madoz y el mismo Olózaga, que asumió su propia defensa, advirtieron que antes de declarar a un diputado susceptible de reelección, se precisaba el informe de la comisión correspondiente, cuya propuesta tenía que haber sido presentada a la mesa de la presidencia veinticuatro horas antes de su discusión y oportuna votación. Como este no era el caso, puesto que los ministros salientes no habían pasado todavía por comisión alguna, los progresistas exigieron su permanencia en la Cámara en calidad de diputados. Ante la imposibilidad de acuerdo, las dos posturas fueron tensando sus argumentos y crispando el ambiente. Madoz llegó a insinuar que Posada ocultaba malas intenciones y declaró que la oposición pretendía despojar a los progresistas hasta del reglamento, entendido como "garantía de los de la minorías ${ }^{\circ}$. Con la demagogia por bandera, los moderados siguieron disimulando hasta manifestar sus vivos deseos por escuchar las explicaciones de Olózaga, a quien de paso, expresaban su mayor apoyo en las actuales circunstancias. Sartorius, el más vehemente en este sentido, incluso recordó a Olózaga que ahora le apoyaban las «mismas personas entre las cuales teníamos antes que poner nuestros pechos para recibir los tiros que se dirigían a su señoría». El final de su intervención lo dedicó a ofrecerle «imparcialidad» y «humil-

\footnotetext{
B8 El Espectador, 1-XII-1843.

${ }^{89}$ D. S., $1-X I I-1843$, p. 304.

so lbid., p. 310.
} 
de apoyo para cuanto necesite». La respuesta de Olózaga fue un nuevo testimonio de su deliberado orgullo y magnífica altivez:

\begin{abstract}
"Le doy las gracias más sinceras por lo que ha tenido la bondad de decirme y ofrecerme; sólo falta que no se lleve las palabras de S. S. el viento, como hasta aquí se ha llevado las del Sr. Posada; sólo falta que S. S. u otro de sus amigos enmiende o modifique la proposición, para que sin perjuicio de estar sujetos a reelección se nos oiga en asuntos personales, y se nos oiga aquí, en este sitio. [...] Yo agradezco mucho esos parapetos que se me ofrecen después de haber pasado el caso. Lo que yo sé decir es que no necesito ninguno, y en cuanto a mi posición, que estoy en la misma que he estado siempre. [...] No he debido, ni quiero deber a personas que no piensen como yo, apoyo ningunon'91.
\end{abstract}

Las recriminaciones al procedimiento de la mesa y a la actitud de Posada alargaron la controversia, hasta que finalmente se sometió a votación una propuesta de Sánchez de la Fuente en la que, por un estrecho margen de cuatro votos, se consiguió pasar el asunto a las secciones para que estas nombraran una comisión encargada de analizar el caso. Resuelta provisionalmente la cuestión, los moderados aprovecharon el calor del debate para introducir sin preámbulo alguno el tema que en realidad interesaba discutir. González Bravo tomó la palabra y sin más rodeos leyó el acta de acusación que la reina había firmado describiendo la ofensa de Olózaga. El nuevo Ministro de Estado, como indicó Valera, se había identificado por completo con su papel y "como nave sin lastre» se decidió, «instigado» por los moderados, a vociferar el "escándalo»92. La lectura del documento provocó la reacción inmediata del imputado, que pidió la palabra para formular una interpelación al gobierno. Pidal no le permitió hablar y a su insistencia para obtener el permiso de intervención, el presidente contestó «no hay palabra». Sólo cuando la sesión estaba a punto de concluir, Olózaga pudo anunciar brevemente su intención de explicar «los medios secretos por que se ha preparado la caída del anterior ministerio, la formación del presente, la instrucción del acta que se ha leído sin haber ministerio y el fundamento de esa actan 93 .

Junto a sus compañeros de gabinete, así lo hizo a lo largo de varios días en los que hubo tiempo para airear todos los detalles sobre la formación del gobierno, los obstáculos que se interpusieton y las razones políticas de su disolución. En la reunión plenaria del día siguiente, el ex-ministro de Gracia y Justicia, Claudio Antón de Luzuriaga, fue el primero en plantear la defensa. Relató pormenorizadamente todo lo ocurrido desde el día 28 en el seno del gobierno, juró no haber conocido que el decreto de disolución hubiera sido obtenido de forma anómala y justificó las tan murmuradas ausencias de Serrano y Frías en

91 Ibid., pp. 313-314.

92 LAfUENTE, M.: Historia General de España ..., Tomo XXII, pp. 408-409.

${ }_{93}$ D. S., 1-XII-1843, pp. 319 y 321 respectivamente. 
sus puestos ministeriales por razones ajenas a la política. Precedido del discurso introductorio de Luzuriaga, Olózaga prosiguió la exposición destacando la incidencia que el comportamiento de Serrano había tenido en el devenir de la situación. Aseguró que el ministro de la Guerra no tuvo noticia alguna sobre la intención de deshacer las Cortes por parte del gobierno, puesto que abandonó el consejo de ministros antes de que se mencionara tal propósito. Pero de lo que sí estaba bien al corriente Serrano era del decreto sobre la revalidación de los empleos concedidos por Espartero que el general no sólo había consentido, sino que incluso - apuntó su jefe de gobierno - tenía dispuesto un decreto similar para su publicación. Desenmascarado por Olózaga, Serrano tomó la palabra para reconocer que, efectivamente, había aceptado el decreto y preparado aquel proyecto, pero que su plan pretendía limitarse a los grados y distinciones, y desde luego no incluía el reconocimiento de la cruz de San Fernando otorgada por Espartero a la Milicia de Madrid. Serrano, delatado por la información del incisivo Olózaga, decidió seguir pregonando otras intimidades del gobierno para el que fue llamado y se cebó particularmente con la que consideraba vanidosa personalidad de su primer ministro. Empezó reprochando a Olózaga su trato distante y la dureza de la que había sido víctima; confesó que nunca tuvo la conciencia tranquila siendo ministro de aquel gabinete y acabó aludiendo a la carta de Narváez con la que se presentó en el consejo de ministros. Serrano, admitiendo que aquel había sido el detonante de la crisis, explicó que el militar en cuestión pretendía dimitir por razones de salud y que también él quería deshacerse de su responsabilidad en cuanto se presentara una ocasión propicia:

«Entonces, el Sr. Presidente del Consejo de Ministros, con un aire que sólo nuestra amistad podía dispensar, me dijo: «Si Vd. hace dimisión del cargo, yo aconsejaré a S. M. que se la admita». Yo contesté lo que creí conveniente entonces; me levanté, tomé mi cartera para irme, y me dijo S. S.: *Tratemos de la dimisión de ese personaje». «Otro tratará de ella, le respondí entonces, porque yo marcho a hacer mi dimisión»m94.

Aún recordó el ministro de la Guerra antes de concluir su intervención, un último motivo de tesentimiento contra Olózaga. Cuando recomendó la participación en el ministerio de un amigo muy querido - refiriéndose a González Bravo-, se le contestó negativamente e incluso se dudó de la lealtad política que dicha persona iba a ser capaz de mantener ante el nuevo gobierno. Serrano declaró tener la prueba de aquella sospecha, escrita por el mismo Olózaga en una carta que le dirigió para advertirle que en cuanto González Bravo le hiciera oposición podía ir renunciando al puesto. En su turno de réplica, el ministro exonerado admitió el contenido de aquel mensaje, pero rectificó la interpretación de Serrano matizando que su verdadera recomendación había consistido

94 D. S., 2-XII-1843, p. 339. 
en dejarle libertad para obrar, si el hombre al que se invocaba daba muestras de su oposición; circunstancia que les constaba a título particular. Es evidente que Olózaga, despechado y con amargo resabio, quiso mostrar de manera ostensible el semblante político de sus adversarios, especialmente González Bravo cuya talia parlamentaria no parecía estar a la altura de lo exigido. A las distintas alusiones, el nuevo ministro de Estado respondió que, recién inaugurado el gobierno precedente, había comunicado a Serrano su convicción de que «debía haberse seguido otro giro» en su formación, pero que no pronunció «ni una palabra de hacerle la oposición "95. Después del careo entre Olózaga y el general Serrano, el ex-ministro de Hacienda, Manuel Cantero, siguió dando más explicaciones y, para aliviar la responsabilidad del acusado, se atribuyó la idea de la disolución y el hecho de haberla aconsejado por si se tenía que hacer frente a un voto de censura.

Oídas en la Cámara, las primeras alegaciones contribuyeron a aumentar el descrédito del ministerio Olózaga. Sus dificultades internas habían quedado palpablemente demostradas, las intynciones de evitar un debate político con la oposición eran síntoma de su debilitud, la arrogancia del que fuera su presidente, había obstaculizado la gobernabilidad; y para que no faltara nada, se había cometido un delito de lesa majestad. Arrollado por una agresión política sin precedentes, los argumentos de Olózaga para sostener su defensa se iban agotando. Los fracasos y deficiencias de su gobierno aún podían discutirse, pero la acusación sobre su comportamiento con la reina era materia extremadamente delicada. La recién inaugurada monarquía de Isabel II era intocable; la figura de la reina, sagrada e inviolable - como sentenciaba la Constitución-; y la palabra de la corona no podía ponerse en duda por más contradicciones que se advirtieran. La prensa moderada se encargó de recalcar este razonamiento y exprimió al máximo su contenido para impedir cualquier frivolidad, desliz o fatal equivocación en este terreno. Con el trono directamente implicado, los moderados sabían que Olózaga no tenía la menor opción y él mismo lo reconoció así en su intervención del día 3, cuando refiriéndose a la corona, tuvo que asumir: "yo no puedo menos de decir lo menos que decirse pueda, sin tocar a lo que no debo tocar»\%.

En efecto, el día 3 de diciembre, el atribulado ex-ministro tuvo por fin la oportunidad de exponer su versión. Pero antes, los moderados volvieron a plantear el asunto de la reelección. Deshaciendo lo acordado, se reconsideró la propuesta aprobada de Sánchez de la Fuente y se sometió de nuevo a votación la que presentara en un principio José de Posada. Al fin, fue esta última la que triunfó. Declarados sujetos a reelección, la rectificación de los enemigos políticos sirvió para privar a Olózaga, Luzuriaga y Cantero de su condición de diputados. «¿Por qué semejante empeño que arguye mala fe? — se preguntaba el

95 Ibid., p. 340.

96 D. S., 3-XII-1843, p. 361. 
Eco del Comercio - ¿por qué aquel deseo de despojar de la investidura de diputado al hombre que se presentaba resuelto y confiado en su inocencia contra una muchedumbre de enemigos?». Además de desestimar la proposición de Sánchez de la Fuente, la oposición - resuelta a anular la influencia política que aún conservaba Olózaga y desacreditar definitivamente su prestigio públicotampoco admitió la que pronunciaron los diputados progresistas Pla y Somoza rogando que no hubiera lugar a deliberar sobre la grave acusación. El Eco lamentó que esta "conveniente idea" no prosperase porque, a su entender, hubiera podido «evitar el escándalo de una discusión, en la cual, si se vota con arreglo al sentido común y a la conciencia, la Reina queda desairada, y si se adopta, por esta causa, una medida contraria, se sacrifica la inocencia y el honor de toda una familia» ${ }^{97}$. Consciente de esa disyuntiva, Olózaga no tuvo más remedio que atender a su dignidad personal y honradez política. Con una incontenida emoción, se refirió al «buen nombre» de su familia y a su «nobleza» probada «sin el más ligero lunar que la empañe». No se trataba de la oratoria acostumbrada, ni del abuso de su locuacidad, sino de la expresión de una nueva norma moral sobre la que descansaba, en definitiva, el proceso de consolidación de la hegemonía burguesa. Como ya daba a entender el Eco del Comercio, aquellos eran valores primigenios a los que ningún revés político podía afectar y cuya perduración no podía ser «sacrificada» bajo ningún concepto:

«Yo entrego mi reputación, señores, en lo que valga de hombre entendido, en lo que valga de Ministro hábil y de hombre público; pero mi vida es mi honra, mi vida es este sentimiento de mi conciencia que me ha hecho vivir conmigo siempre tranquilo y contento; mi vida es, señores, la que debo a un padre honrado. [... $]$ Mi vida es la que he pasado con una persona de mi corazón, con mi hija ..., la que he pasado con mis amigos ..., con mis compañeros que me han creído siempre hombre de bien, incapaz de faltar a mis deberes ..., y, señores, iesto no puedo yo sacrificarlo ni a la Reina, ni a Dios, ni al universo entero!!! iHombre de bien, inocente, he de aparecer ante el mundo aunque fuera en la escalera de la horca!!! A todas partes voy, señores; todo lo hago, todo lo sacrifico, todo lo acepto, menos el pasar por hombre indignow 98 .

El tono lastimero de sus primeras palabras se transformó al día siguiente en un enérgico discurso. Con mayor profundidad política y más decisión, Olózaga abordó la cuestión de la monarquía de la única forma que era posible hacerlo. Si la declaración de la teina no se podía desmentir sin arriesgarse a cometer un error todavía más grave, al menos había que intentar demostrar la deslealtad constitucional y política de sus pérfidos consejeros. Olózaga atribuyó toda la responsabilidad de la crisis a los «desatentados cortesanos» que de manera

${ }_{97}$ Eco del Comercio, 4-XII-1843.

${ }_{98}$ D. S., 3-XII-1843, p. 361. 
irresponsable hacian «jugar un papel indigno" a la corona y la utilizaban como mero «instrumento" de sus «intereses, ambiciones y miserias" 99 .

El impacto de sus afirmaciones provocó una mayor polarización de las posturas políticas. La prensa progresista extremó su protección a Olózaga, mientras los diarios moderados no daban tregua al que, según su punto de vista, cada día llevaba más lejos su insolencia y se reafirmaba en su desacato. Toda la literatura política de la época alabó su arrogancia y valentía, pero en opinión de Rico y Amat no fue sólo una cuestión de honor la razón principal que motivó la defensa de Olózaga:

"Ante una acusación tan grave, ante el anatema general [...] muchos creían que el señor Olozaga retrocediese espantado [...]. No conocían los que así pensaban el temple de alma del infortunado ministro. El Sr. Olózaga, como todo hombre que estima su honra ante todo, no podía abandonar el campo a sus enemigos con una vergonzosa fuga, y debía subir al cadalso, a ser preciso, proclamando su inocencia, fuese o no fuese inocente. Y no era sólo una cuestión de honra la que allí se ventilaba. Eran además, el porvenir y el crédito del partido progresista los que estaban comprometidos, y el Sr. Olózaga, como jefe de aquel partido, debía sacar sin mancha su bandera, aunque pereciese en el combate. Por eso se presentó en el Congreso el Sr. Olózaga, sereno sin altivez, resignado sin humillación, animoso sin procacidad» 100 .

Ni sus conclusiones, ni las de los ex-ministros de su gabinete, ni tampoco los apoyos que le llegaron de amigos políticos -especialmente Madoz, Cortina y Joaquín María López - pudieron contener el golpe de la oposición. El 7 de diciembre, un grupo de diputados entre los que figuraban Fermín Gonzalo Morón, José de Posada y Nicomedes Pastor Díaz, presentó en el Congreso un proyecto de ley que proponía ejecutar el artículo 40 de la Constitución:

«Convencidos los infraescritos Diputados de que no seríamos leales para con nuestra Reina y nuestra Patria si después de leída en el Congreso la declaración solemne de S. M. no usásemos contra D. Salustiano de Olózaga, Ministro exonerado de Estado, del derecho que concede al Congreso el párrafo cuarto del art. 40 de la Constitución, acusamos al Sr. Olózaga como reo de abuso de confianza, de desacato y coacción contra la augusta persona de S. M. y pedimos al Congreso que se sirva declarar que ha lugar a juzgar a $\mathrm{D}$. Salustiano de Olbzaga, y nombrar los Diputados que con arreglo al artículo 12 del apéndice del reglamento deben sostener la acusación en el Senado»101.

9 D. S., 4-XII-1843, p. 373.

ioe Rico y Amat, J.: Historia Politica ..., Vol. III, p. 419.

${ }_{101}$ D. S., 7-XII-1843, Apéndice Primeto, p. 441. 
En la Constitución de 1837, el párrafo cuarto del artículo 40 permitía «hacer efectiva la responsabilidad de los Ministros, los cuales serán acusados por el Congreso y juzgados por el Senadom ${ }^{102}$. Sobre la aplicación de este artículo no había antecedentes en el constitucionalismo español. Entre otras cosas, la fórmula exa vaga y requería un desarrollo legislativo capaz de regular con precisión todo lo relacionado con la responsabilidad penal de los ministros. La elaboración de una ley en este sentido, sugerida desde un primer momento en el Estatuto Real, registró su mayor avance durante el gobierno de Mendizábal, que en 1835 llegó a presentar un proyecto cuya discusión y aprobación se vio truncada por los acontecimientos que dieron lugar a la clausura de las Cortes en mayo de 1836. Posteriormente, en vigencia de la Constitución de 1837 y pese a que el gobierno de López prometió una ley de responsabilidad ministerial, tampoco se lievó a efecto el necesario complemento legal, limitando así la aplicación del artículo $40^{103}$. No obstante, aún sabiendo que se interponía una considerable dificultad constitucional, el grupo de Posada suscribió la propuesta con la intención de humillar a Olózaga. Era evidente, diría Fernández de los Ríos años después, que "no se quería juicio sino sacrificio»" ${ }^{104}$.

La posibilidad de juzgar al presidente depuesto fue defendida en el Congteso por Posada y apoyada vivamente por Bravo Murillo. Mientras los periódicos moderados, azuzando a sus representantes parlamentarios, clamaban por llegar hasta las últimas consecuencias; la prensa progresista exigía desistir del intento. El Eco del Comercio aconsejaba no llevar las cosas al «extremo", ser "prudentes" para no seguir dañando la institución monárquica y reflexionar acerca de la nula "ganancia» que quedaría al país de continuar adelante con el proceso judicial ${ }^{105}$. Conscientes de que el hundimiento de Olózaga les dejaría sin timón y el partido mismo acabaría deteriorado, los diputados progresistas, en un último esfuerzo para evitar el escarnio, intentaron retrasar el debate parlamentario, utilizando todos los recursos autorizados por el reglamento para interrumpir el ritmo de las sesiones. El resultado de la estrategia pudo verse cuando el consejo de Ministros del día 11 de diciembre debatió la urgencia de disolver las Cortes. Algunos miembros del nuevo gobierno eran partidarios de esperar hasta que se votara la acusación de Olózaga, pero González Bravo, jefe del gabinete y Ministro de Estado, se mostró convencido de que no ocurriría tal cosa y «manifestó [...] que la acusación del Sr. Olózaga no llegaría nunca a votarse por las facilidades que, para dilatarla sin término, el reglamento concedía» ${ }^{106}$. Pero

${ }^{102}$ PONS Y UMBERT, A.: Organización y funcionamiento de las Cortes según las Constituciones españolas, Congreso de los Diputados, Madrid, 1992 [1906], p. 312.

103 Véase al respecto, MARCuello BENEDICTO, J. I.: La práctica parlamentaria en el reinado de Isabel 1I, Congreso de los Diputados, Madrid, 1986, pp. 184-188.

104 FERNANDEZ DE LOS Ríos, A.: Olozaga ..., p. 459.

105 Eco del Comercio, 10-XII-1843.

106 Archivo Central del Ministerio de la Presidencia, Actas del Consejo de Ministros, 1843, A 1-11, ff. 9-10. 
esta no era la única razón para el pesimismo, porque las Cortes acababan de nombrar, el día anterior, la comisión que se encargaría de examinar la acusación contra Olózaga. Teniendo en cuenta que la formaban Madoz, Joaquín María López, Cortina, Moreno López, Ayllón, Posada y Pastor Díaz, era lógico pensar que, siendo los progresistas mayoría, se iba a ralentizar el trabajo de la sección hasta donde fuera posible ${ }^{107}$.

Olózaga, desacreditado y expulsado de la vida política, prefirió no asistir al desenlace y el día 13 de diciembre salió de Madrid, camino de Portugal, hacia su segundo exilio.

\section{LA ANULACIÓN DEL PROGRESISMO Y LOS INICIOS DE LA DÉCADA MODERADA: UNA CONSIDERACIÓN FINAL.}

La desaparición del ministerio Olózaga —el primer gabinete formado bajo el reinado oficial de Isabel $\amalg$ - puso fin a tres años de gobierno progresista y dejó paso a una larga etapa de política moderada. Para la estrategia templada del liberalismo había llegado el momento de corregir las desviaciones que el progresismo generaba. Los principios de ambas tendencias coincidían en lo esencial del proyecto político. Es evidente que los moderados rechazaban la más mínima aspiración democrática, pero tampoco los progresistas -a pesar de que en ocasiones se les ha atribuido una mayor sensibilidad social- contemplaban esa posibilidad. Sin embargo, la creciente presencia de demandas populares se refugiaba, a falta de organizaciones propias todavía embrionarias, en las grietas que había abierto el progresismo recurriendo, no pocas veces, a la colaboración ciudadana para conquistar su espacio político. Con esa rémora que empañaba su imagen, no resultaba saludable compartir el poder y no era conveniente para los intereses mayoritarios de la burguesía liberal correr riesgos innecesarios. Dotado el sistema de monarquía constitucional y construidos los pilares del régimen parlamentario, no cabía hacer concesiones que malograran las metas alcanzadas y pusieran en peligro su consolidación. Era prioritario mantener un orden estricto para garantizar un recorrido político sin sobresaltos y, en consecuencia, urgía invalidar la versión avanzada del liberalismo.

En este contexto, Olózaga se había convertido en un verdadero obstáculo para el desarrollo del programa moderado. Su papel en el escenario político a finales de 1843 no era el de un diputado común ni el de un presidente más. Los moderados, persuadidos de su valía y estimando lo oportuno de adquirir aquel producto, intentaron ganarlo para su causa. Pero Olózaga, después de utilizar su apoyo para llegar al poder, frustró las expectativas moderadas con gestos de inequívoca fidelidad a los principios progresistas. Como las circunstancias hacían suponer, su gobierno fue efímero; aunque cabe preguntarse por

\footnotetext{
${ }_{107}$ D. S., 10-XII-1843, p. 492.
} 
qué en esta ocasión la caída del ministerio fue acompañada por un escándalo político, cuya desproporción superaba los límites de un simple acuerdo para cambiar uno más de los muchos gabinetes establecidos hasta ahora.

No era suficiente la sustitución del gobierno $y$, esta vez, tampoco bastaba la crítica o el debate político. Los moderados buscaban desautorizar la alternativa opuesta y cercenar sus posibilidades de continuar en el poder. La figura de Olózaga había alcanzado tanto peso que la neutralización del progresismo exigía su derrota definitiva. Olózaga era la cabeza visible de los progresistas y la única autoridad reconocida que podía dirigir su política con un amplio consenso. Privar al progresismo de su mejor conductor equivalía a anular sus efectos políticos por mucho tiempo. La eliminación de Olózaga dejó huérfano al progresismo que no tenía, en aquellos momentos, recambio alguno para sustituir su poderosa presencia. Expulsado el único dirigente capaz de reagrupar y canalizar las aspiraciones políticas de los progresistas, los moderados pudieron inaugurar una década de gobierno estable. 